\title{
Naturally Occurring Oxazole-Containing Peptides
}

\author{
Jessica T. Mhlongo 1,2,+, Edikarlos Brasil 1,2, ${ }^{1}$, Beatriz G. de la Torre ${ }^{1,2, *(D)}$ and \\ Fernando Albericio 1,3,*iD
}

1 Peptide Science Laboratory, School of Chemistry and Physics, University of KwaZulu-Natal, Durban 4001, South Africa; jtmhlongo91@gmail.com (J.T.M.); MacedoBrasilE@ukzn.ac.za (E.B.)

2 KwaZulu-Natal Research Innovation and Sequencing Platform (KRISP), School of Laboratory Medicine and Medical Sciences, College of Health Sciences, University of KwaZulu-Natal, Durban 4041, South Africa

3 CIBER-BBN (Networking Centre on Bioengineering, Biomaterials and Nanomedicine) and Department of Organic Chemistry, University of Barcelona, 08028 Barcelona, Spain

* Correspondence: garciadelatorreb@ukzn.ac.za (B.G.d.l.T.); albericio@ukzn.ac.za (F.A.); Tel.: +27-614009144 (F.A.)

+ These authors contributed equally to this work.

Received: 4 March 2020; Accepted: 7 April 2020; Published: 10 April 2020

check for updates

\begin{abstract}
Oxazole-containing peptides are mostly of marine origin and they form an intriguing family with a broad range of biological activities. Here we classify these peptides on the basis of their chemical structure and discuss a number of representatives of each class that reflect the extraordinary potential of this family as a source of new drugs.
\end{abstract}

Keywords: marine natural products; solid-phase peptide synthesis; heterocycles

\section{Introduction}

Peptides play crucial and diverse biological roles as signaling and regulatory molecules in various physiological and pathological processes, such as defense, immunity, stress, growth, homeostasis, reproduction, and other cell functions [1]. Due to their optimized synthesis, bio-specificity, and efficacy profile in humans, peptides provide a platform for the design of novel therapeutic drugs [2,3]. However, the use of these molecules as therapeutics is limited because of their cell membrane and blood-brain barrier impermeability, poor chemical and physical stability, and short plasma half-life [4].

These limitations have brought about a systematic search for peptidomimetics [5,6], such as oxazole-based peptides. Oxazoles are an important class of 5-membered $\mathrm{N}, \mathrm{O}$-heterocyclic compounds with numerous applications, from medicines to agrochemical products. The presence of oxazole moieties in natural peptides confers stability and/or electronic distribution to the peptide chain, thereby enabling peptide-protein recognition and DNA/RNA-peptide interactions [7]. Furthermore, oxazoles show antibacterial [8,9], antiviral [10], antimalarial [11], and anti-algal properties [12], as well as cytotoxic activity [13], among others [14].

Oxazole-containing peptides are mostly of marine origin and can be formed via ribosomal and non-ribosomal mechanisms, as well as through synthetic means. The biosynthetic pathways, either via ribosomal or non-ribosomal processes, involve the heterocyclization of $\beta$-hydroxyl residues, mainly serine (Ser)/threonine (Thr), into an oxazoline moiety, followed by an oxidation step catalyzed by flavin mononucleotide (FMN)-dependent dehydrogenase (Scheme 1). In addition, several synthetic methodologies to prepare oxazole rings have been reported in detail [15-17].

Here we review the isolation, structural elucidation, and biological activity of some representatives of each class of the natural oxazole-containing peptides: short linear, long linear, cyclic, bicyclic, an thio peptides. 


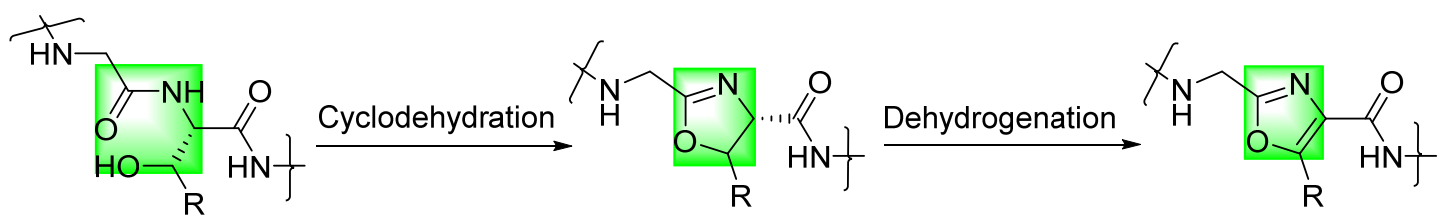

Scheme 1. Biosynthesis of oxazoles.

The division between small and long peptides (Section 3) has been decided by the authors and applies only to this work.

\section{Short Linear Peptides}

\subsection{Almazoles $A-D$}

Between 1994 and 1996, N'Diaye et al. [18,19] and Guella et al. [20] reported the dipeptide 2,5-disubstituted oxazoles A-D (1-4 in Figure 1), unusual structures isolated from Delesseriaceae marine alga, found on the coast of Senegal. Named almazoles by the authors, the structures of $\mathbf{3}$ and 5 show an indole moiety. The stereochemical assignment was determined by biomimetic synthesis. However, for the original assigned structure of 4, a revised structure of this compound (5) via chemical synthesis was reported [21]. Compound D (5) differs from 3 in that its biogenesis conceivably involves oxidative deamination rather than decarboxylation of Trp, hence rationalizing both the extra carbonyl group and the hydroxyl group at the oxazole ring. No biological testing has been reported for 1-3. Regarding 5, it showed potent antibacterial activity against Gram-negative Serratia marcescens and Salmonella typhi [19].

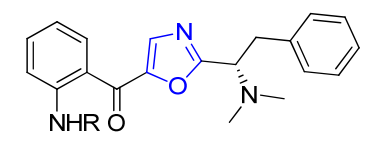

Almazole $\mathrm{A}(1) \mathrm{R}=\mathrm{CHO}$ Almazole B (2) $\mathrm{R}=\mathrm{H}$

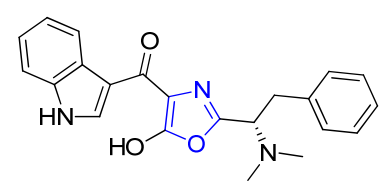

Assigned structure of Almazole D (4)

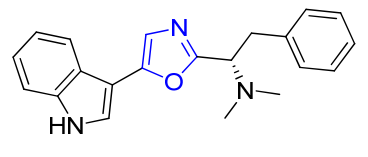

Almazole C (3)

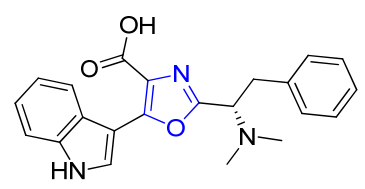

Revised structure of Almazole D (5)

Figure 1. Structures of Almazoles A-D.

Lade et al. also synthesized the two stereoisomers of $\mathbf{5}$ and evaluated their anti-tuberculosis activity. The hybrid 5-(3-indolyl)oxazole scaffold of these compounds displayed drug-like properties and revealed promising activity against Mycobacterium tuberculosis (Almazole D (5), MIC $=100 \mu \mathrm{M}$; R-enantiomer, $\mathrm{MIC}=12.5 \mu \mathrm{M}$ ) [22].

\subsection{Martefragin $A$}

Takahashi et al. isolated the secondary metabolite named Martefragin A (6) from the red algae Martensia fragilis Harvey (Figure 2) [23]. The structure features a trisubstituted 2,4,5-oxazole ring, in which the indole moiety, originated from a $\beta$-hydroxyl-Trp group, is directly linked to $\mathrm{C} 5$, a carboxylate group at $\mathrm{C} 4$ and a branched five-carbon side chain bearing two stereocenters at $\mathrm{C} 2$. The structural assignment was established based on spectroscopic and X-ray crystal analyses, and the absolute configuration of the stereocenter carbon atoms was determined through total synthesis studies [24]. Compound 6 has been reported to be an inhibitor of lipid peroxidation in biological systems [23]. 


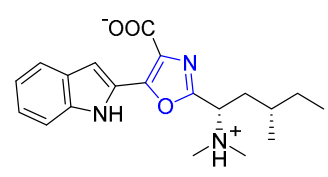

Figure 2. Structure of Martefragin A.

\subsection{Muscoride A}

(-)-Muscoride A (7) is an oxazole peptide alkaloid that was isolated by Nagatsu et al. from terrestrial freshwater cyanobacterium Nostoc muscorum (Figure 3) [25]. Featuring a bis-5-methyloxazole moiety and a prenyl-like functionality at the $\alpha$-nitrogen atom of a Val residue, the structure of 7 has a unique chemical architecture among the class of alkaloids. The construction of the bis-oxazole rings has been proposed to arise from two Thr units that undergo a sequence of cyclodehydration-oxidation reactions [26]. In addition, unlike some reported indole-based natural products that commonly show the presence of the reverse prenyl functional group, this secondary metabolite is among the first bisheterocyclic-oxazole alkaloids to have such functionality (N-(2-methyl-3-buten-2-yl). Although 7 has shown only modest antibiotic activity, and no further biological tests have been performed, several research groups have used it as a platform to test the efficiency of a series of synthetic methodologies for the regioselective assembly of oxazole compounds [27]. To this end, the total synthesis of 7 was achieved soon after its first isolation by Nagatsu et al., thereby providing additional structural information about the initial unresolved stereochemistry of the molecule, such as its relative and absolute configuration [28].

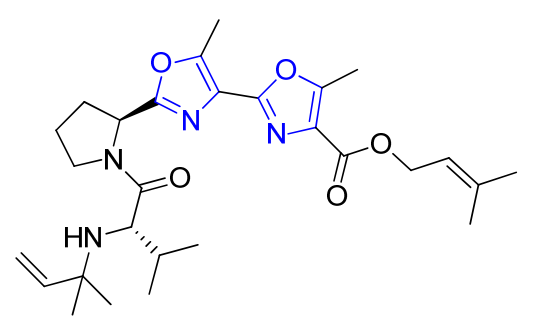

(-)-Muscoride A (7)

Figure 3. Structure of (-)-Muscoride A.

\section{Long Linear Peptides}

\subsection{Microcin B17}

Microcin B17 (MccB17) (8) is a post-translationally modified peptide that was isolated from Escherichia coli strains (Figure 4) [29]. Of the 43 amino acids comprising its structure, the peptide backbone contains 20 Gly units, and 14 amino acids are post-translationally modified, represented by the eight 5-membered heterocycles—oxazole/thiazole rings. Genetic studies of MccB17-producing strains revealed that, of the seven operon genes involved in the biosynthesis of this peptide, at least three gene products code for modifications of certain Ser and Cys residues in the heterocyclic backbone residues, including the two 4,2-fused heterocyclic rings [30]. A full structural characterization of 8 was carried out using several analytical techniques, as well as 2D NMR spectroscopy and ${ }^{15} \mathrm{~N}$-labeled peptides [31]. This natural Gly-rich polypeptide belongs to a class of DNA-gyrase inhibitors. Other classes of these inhibitors include quinolones and coumarins [30,31]. Evaluation of the bioactivity of 8 against E. coli cells suggested potent antibacterial activity by targeting the double-strand DNA, ultimately leading to cell death. However, a series of mutagenesis experiments indicated that alteration of the number of rings, their chemical nature, and their position along the peptide chain directly affect the antibiotic efficacy of this compound [7]. In this regard, substitutions of the 4,2-tandem bisheterocycle (thiazole-oxazole) moiety with 4,2-fused bisheterocycles ((oxa)thiazole-(oxa)thiazole) in the native MccB17 structure had a significant effect on the biological activity of the compound. The possibility of 
designing a library of MccB17 analogs for further biological evaluation led synthetic chemists to work on the total synthesis of this natural product, which has been accomplished successfully [31-33].

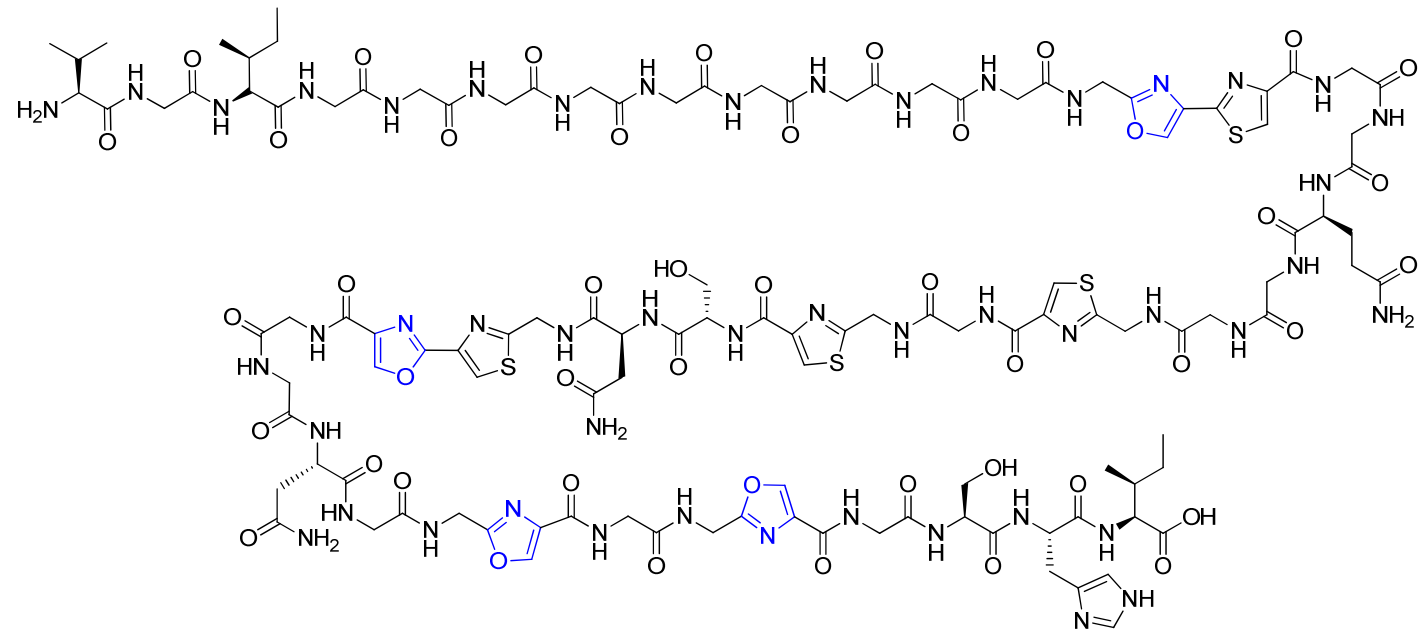

Microcin B17 (8)

Figure 4. Structure of Microcin B17.

\subsection{Plantazolicins $A$ and $B$}

Plantazolicins A (9) and B (10) (Figure 5) isolated from Bacillus amyloliquifaciens FZB42 have biosynthetic pathways resembling that of Microcin B17 (8), and they are classified as thiazole/oxazole-modified microcins (TOMMs). The biosynthetic gene cluster machinery of Plantazolicin consists of 12 genes that are involved in the synthetic process of this secondary metabolite, as well as in modification, export, and self-immunity mechanisms. Specifically, the heterocyclization of Cys and Ser/Thr residues into the azole rings highlights a series of post-translational modifications, which are encoded by a trimeric BCD protein complex (a cyclodehydratase (C), a dehydrogenase (B), and a docking protein (D)) [34].

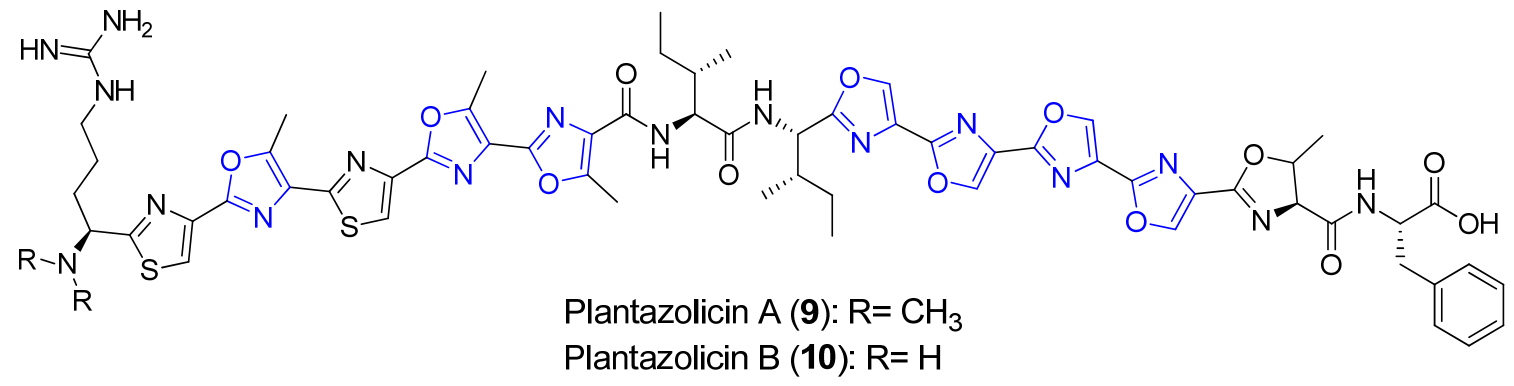

Figure 5. Structures of Plantazolicin A and B.

Structures 9 and $\mathbf{1 0}$ have a limited number of protons, due to the presence of ten heterocycles within their structures plus a phenyl group. To determine the molecular structure of these compounds, ${ }^{15} \mathrm{~N}$-labeling experiments were undertaken, together with a series of other spectroscopic techniques. On this occasion, two important questions were raised during structural assignment: (i) whether the enzymatic dimethylation step of $\mathbf{9}$ and $\mathbf{1 0}$ installed the methyl groups at the $\mathrm{N}$-terminal amine or at the alkyl side chain of an Arg residue, and (ii) the position of the exact site of the oxazoline heterocycle. These questions were addressed using the mass spectrometry technique known as collision-induced dissociation (CID). It was observed that the $\mathrm{N}$-terminal ion fragment contained the two post-translational methyl groups, and the C-terminal fragment showed the oxazoline moiety $[35,36]$. When screened on a variety of Gram-positive/Gram-negative organisms, 9 displayed discriminating antibiotic activity against Bacillus anthracis, but no activity on Gram-negative organisms [34,35]. 


\subsection{Goadsporin}

In 2001, Onaka et al. reported the isolation and characterization of Goadsporin (11) from Streptomyces sp. TP-A0584 (Figure 6). According to NMR analysis, the structure of $\mathbf{1 1}$ consists of 19 amino acids (ATVSTILCSGGTLSSAGCV), with AT/ST/GT/SS pairs of L-amino acids, resulting in the formation of four oxazole rings and the condensation of LC/GC amino acids, thereby furnishing two thiazole units. The structure also shows an acetylated $N$-terminal and two dehydroalanine residues, which are formed by glutamylation of Ser, followed by glutamate elimination, as suggested by a recent study [37]. Finally, the L-configuration of the amino acids was determined by Marfey's method. Compound $\mathbf{1 1}$ belongs to the class of ribosomally synthesized and post-translationally modified peptides (RiPPs) and it has potent biological properties against Streptomyces spp. and S. scabies, which is the organism that causes potato scab. When screened on a range of other Streptomyces strains, $\mathbf{1 1}$ induced the formation of several other secondary metabolites and also caused sporulation. These properties have generated interest in the total synthesis of 11, which has been successfully accomplished [38].

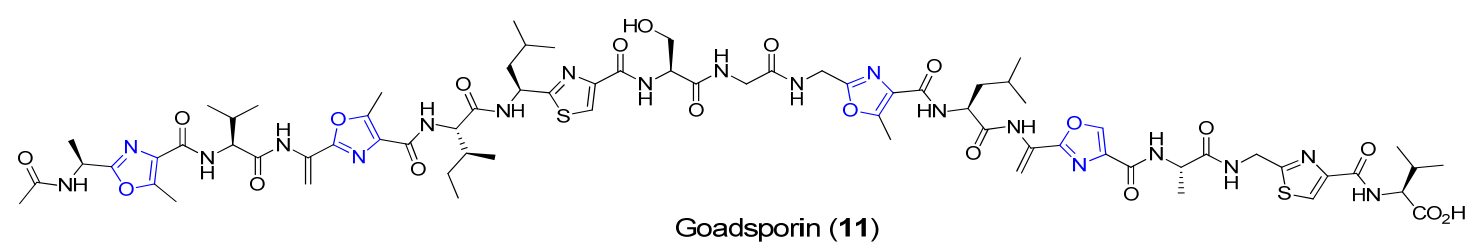

Figure 6. Structure of Goadsporin.

\section{Cyclic Peptides}

\subsection{Bistratamides $C, D, G, H, I, M$, and $N$}

Bistratamides C, D, G, H, I, M, and N (12-18) are cyclic hexapeptides that were isolated from the cytotoxic extract from the ascidian Lissoclinum bistratum (Figure 7) [39,40]. Sharing a similar cyclic backbone, the structures of 12-18 were determined by means of 2D NMR spectroscopy, as well as mass spectrometry. The metabolites $\mathbf{1 2}$ and $\mathbf{1 3}$ from the northern Philippine ascidian L. bistratum, studied by Ireland's group in 1992, show one oxazole/two thiazole rings, and one oxazoline/one thiazole/one oxazole ring in their structures, respectively. Regarding the amino acid residues present in $\mathbf{1 2}$ and 13, the former has one Ala and two Val residues and the latter three Val residues. When introduced directly into the central nervous system (CNS) of mice, 13 exhibited neurodepressant properties [41].

A decade later, Bistratamide G-I (14-16) were reported in the literature [39]. In addition to being isolated from the same organism as 12 and 13, compounds 14, 15, and 16 all have three Val residues. However, they differ from one another in the number and type of residues that give rise to the heterocycles oxazole and thiazole, and $\mathbf{1 6}$ is the only compound with a Thr unit. Bistratamides 14, 15, and 16 were found to be moderately cytotoxic in an HCT-116 cell line assay [39].

Two additional bistratamides with antitumor activity, $\mathrm{M}(\mathbf{1 7})$ and $\mathrm{N}(\mathbf{1 8})$, were also characterized, as reported by Urda et al. Overall, the ${ }^{1} \mathrm{H}$ NMR data of $\mathbf{1 7}$ and $\mathbf{1 8}$ presented a similar pattern to that of Dolastatin E (30) [40]. Of note, the structures of the peptides westiellamide [42], Dendroamides 19-21 [43], and Nostocyclamides 22 and 23 [12] are all related to Bistratamides 12-18. 


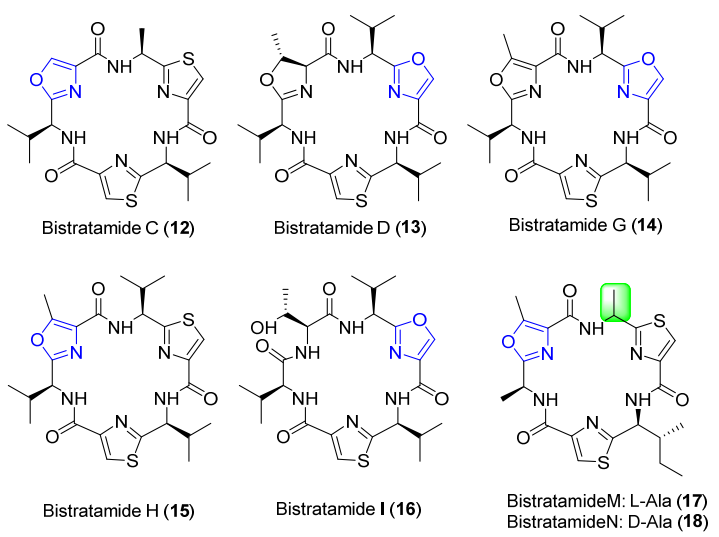

Figure 7. Structures of Bistratamide C, D, G, H, I, M, and N.

\subsection{Dendroamides $A-C$}

First reported by Ogino et al., Dendroamides A-C (19-21) are bistratamide-type cyclic hexapeptides that were isolated from the terrestrial blue-green alga Stigonema dendroideum Fremy (Figure 8). The structures of 19-21 were fully characterized as featuring one methyloxazole, two thiazole moieties, and three amide groups, from which an 18-membered cycle is formed. Although having the same basic skeleton-as determined by chemical degradation, NMR, and EIMS experiments-19-20 differ from one another in the type of amino acid side-chain residues. In this regard, Val, Met, and methionine sulfoxide $(\operatorname{Met}(\mathrm{O}))$ groups are present in Dendroamides A, B, and C, respectively. Dendroamide A (19) was evaluated as a potent MDR-reversing agent against breast carcinoma (MCF-7/ADR) cells, while 20 and 21 showed no activity. The total synthesis of 19 has been successfully accomplished [44-46].<smiles></smiles>

Dendroamide A (19)<smiles></smiles>

Dendroamide B (20)<smiles>Cc1cnc([C@@H](C)NC(=O)c2csc([C@@H](CCS(C)=O)NC(=O)c3csc([C@@H](C)NC(=O)c4nc(C)oc4C)n3)n2)o1</smiles>

Dendroamide C (21)

Figure 8. Structures of Dendroamide A-C.

\subsection{Nostocyclamides}

Nostocyclamide (22) and Nostocyclamide M (23) (Figure 9) were isolated by Todorova et al. from the freshwater cyanobacterium Nostoc 31. The former has oxazole/thiazole rings linked by Gly, Val and Ala residues, while in the latter they are linked by Gly, Ala, and Met. Structural assignment based on $2 \mathrm{D}$ NMR data and ${ }^{15} \mathrm{~N}$ labeling experiments revealed three heterocycles (an oxazole ring and two thiazole rings), including the other substituents highlighted above. The absolute configuration of the methine-Ala and methine-Val carbons, as $S$ and $R$, respectively, was determined through X-ray crystallographic studies. Both 22 and $\mathbf{2 3}$ have cyanobacterial and allelopathic activity, and the former also shows anti-algal activity $[12,47]$. 
<smiles>Cc1cnc([C@@H](C)NC(=O)c2csc([C@@H](NC(=O)c3csc(CNC(=O)c4coc(C(C)C)n4)n3)C(C)C)n2)o1</smiles>

Nostocyclamide (22)<smiles></smiles>

Nostocyclamide M (23)

Figure 9. Structures of Nostocyclamides.

\subsection{Tenuecyclamides $A-D$}

Tenuecyclamides A-D (24-27) (Figure 10) were isolated as patellamide-like compounds from the Nostoc spongiaeforme var. tenue Rao (Nostocales, Nostocaceae), collected in Bet Dagan, Israel, by Carmeli et al. The planar structures of 24-27 were determined by 2D-NMR techniques and high-resolution mass spectrometry measurements. The $\mathrm{MeOH}$ extract of the freeze-dried cyanobacterium showed antimicrobial activity (against Bacillus subtilis and Staphylococcus aureus) and inhibited the division of embryos of the Mediterranean sea urchin. Compounds 24 and 25 contain three Ala residues, two thiazoles and one methyloxazole; however, they differ from each other in the stereochemistry of the Ala residues. Compound 26, in turn, contains Gly, Ala, and Met, two thiazoles and one methyloxazole. Marfey's method failed to fully solve the stereochemistry of 24 and 25. However, for $\mathbf{2 6}$ and 27, the stereo-assignment confirmed the L-forms of the amino acid residues [48].<smiles>Cc1oc(C(C)C)nc1C(=O)N[C@@H](C)c1nc(C(=O)NC(C)C)cs1</smiles>

Tenuecyclamide A (24)

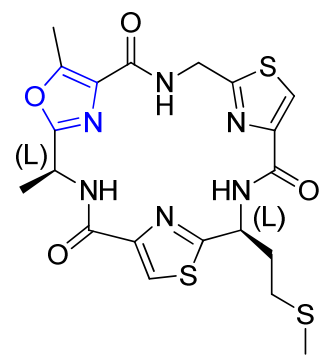

Tenuecyclamide C (26)<smiles>COc1nc(C(=O)NC(=O)c2csc(-c3nc(C(=O)NC(C)C)cs3)n2)cs1</smiles>

Tenuecyclamide B (25)<smiles></smiles>

Tenuecyclamide D (27)

Figure 10. Structures of Tenuecyclamide A-D.

\subsection{Venturamides $A$ and $B$}

Using antimalarial bioassay-guided fractionation, Linington et al. isolated Venturamide A (28) and B (29) from the marine cyanobacterium Oscillatoria sp. (Figure 11), collected in Buenaventura Bay (Colombia). Both 28 and 29 showed strong in vitro activity against Plasmodium falciparum and mild cytotoxicity to mammalian Vero cells. They have also shown mild activity against Trypanasoma cruzi, Leishmania donovani, and MCF-7 cancer cells. The structures were characterized by 1D and 2D NMR spectra, which revealed that $\mathbf{2 8}$ has a Val residue and two thiazole rings. On the other hand, 
the structural characterization of $\mathbf{2 9}$ unveiled that it contains Thr in the place of Ala, adjacent to the thiazole ring. Marfey's analysis showed that all the amino acids of these two peptides have a D-configuration [11].

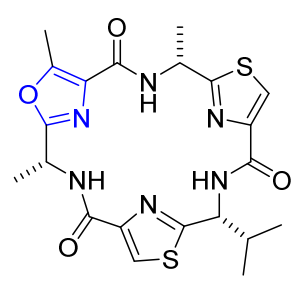

Venturamide A (28)

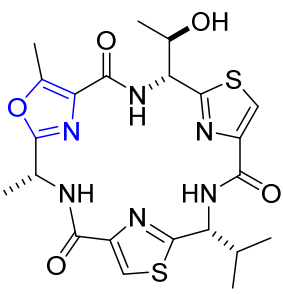

Venturamide B (29)

Figure 11. Structures of Venturamide A and B.

\subsection{Dolastatins E and I}

The macrocyclic hexapeptides Dolastatin E (30) and I (31) were obtained from the sea hare Dolabella auricularia by Ojika et al. and Sone et al. (Figure 12), respectively [49,50]. Remarkably, in spite of being isolated from distinct organisms, the natural cyclic peptides Bistratamides 12-18, Raocyclamides 32a and 32b, Nostocyclamides 22 and 23, and Dendroamides 19-21 are among the 18-membered macrocycles with structures similar to those of Dolastatins 30 and 31 . One major difference between the chemical structure of Dolastatin 30 and the structures in the group of the hexapeptides outlined above, including Dolastatin 31, is the presence of a semi-oxidized heterocyclic thiazoline, post-translationally modified from Cys and Ala residues [49]. To fully characterize the stereochemistry of $\mathbf{3 0}$, which could only be partially assigned as $5 R / 6 S$ by acid-catalyzed hydrolysis and ozonolysis experiments, the total synthesis of this metabolite was necessary. In this regard, Nakamura et al. synthesized $\mathbf{3 0}$ and observed that it contained the following amino acid units with their respective stereochemical assignment: L-Ala, D-Ala, allo-D-Ile, and D-Cys. However, no chirality was determined for Ser or Cys, as these residues underwent heterocyclization to form the oxazole and thiazole rings, respectively [51].
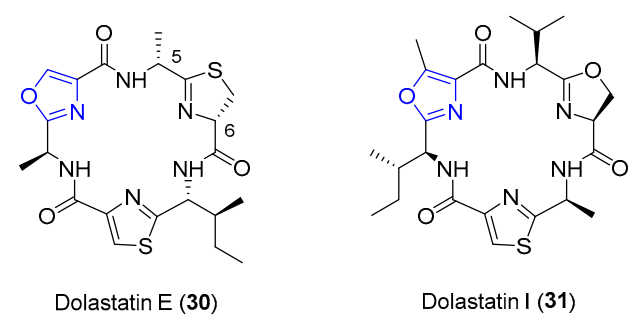

Figure 12. Structures of Dolastatin E and I.

Conventional ${ }^{1} \mathrm{H}-{ }^{1} \mathrm{H} /{ }^{1} \mathrm{H}-{ }^{13} \mathrm{C}$ NMR correlations and mass spectral data revealed that the structure of 31 contains two heteroaromatic rings and one oxazoline moiety, as well as Val, Ile, and Ala residues. By subjecting this compound to chemical degradation conditions, it was observed that all the amino acids in the structure adopted the L-configuration. Compounds $\mathbf{3 0}$ and $\mathbf{3 1}$ showed weak cytotoxicity on tumor HeLa-S3 cells [50].

\subsection{Raocyclamides $A-B$}

In the search for versatile structures from cyanobacterium Oscillatoria raoi with potent biological activities, Admi et al. isolated Raocyclamides A (32a) and B (32b) (Figure 13). The structures of these two cyclic hexapeptides share the same number of amino acid residues (Ala, Ser, Phe, Cys, and Ile), as indicated by chemical degradation experiments, as well as spectroscopic and MS data. The structure of $\mathbf{3 1}$ differs from that of $\mathbf{3 2}$ in that it has three heterocyclic units, among which a 5-membered N,O-based 
heterocycle appears in its oxazoline oxidation state. In 32, the oxazole and the thiazole rings are post-translationally modified but no modification is observed between Ser and the carbonyl group of Phe. Compound $\mathbf{3 1}$ is moderately cytotoxic against sea urchin embryos. No further bioactivity has been reported for 31 or 32 [52]. The total synthesis of $\mathbf{3 1}$ and $\mathbf{3 2}$ was undertaken by Freeman et al., and it was concluded that their structures contained L-Ile rather than D-isoleucine, as previously reported [53].

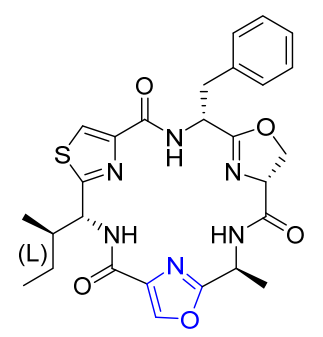

Raocyclamide A (32a)

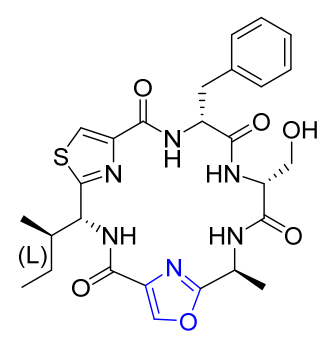

Raocyclamide B (32b)

Assigned stereochemistry: D-isoleucine

Revised stereochemistry: L-isoleucine

Figure 13. Structures of Raocyclamide A and B.

\subsection{Microcyclamides}

In 2000, Ishida et al. isolated the first cyclic hexapeptide microcyclamide (33) from the freshwater cyanobacterium Microcystis aeruginosa NIES-298 (Figure 14). The structural assignment was determined by 2D NMR spectroscopy, revealing the following fragments: a thiazole-methyl histidinyl; a thiazole-isoleucinyl; and a methyloxazole-alanyl. Additionally, ozonolysis/hydrolysis experiments and Marfey's analysis fully established the stereochemistry of the structure of 33. Biological evaluation of 33 revealed cytotoxicity towards P388 murine leukemia cells at IC $501.2 \mu \mathrm{g} / \mathrm{mL}$ [54].

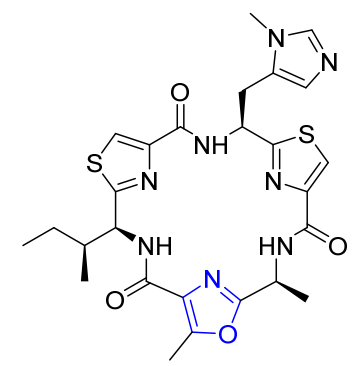

Microcyclamide (33)

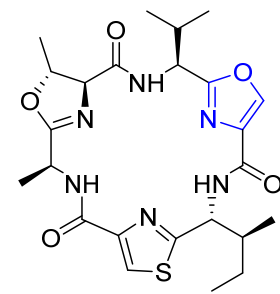

Original structure of Microcyclamide 7806A (34)

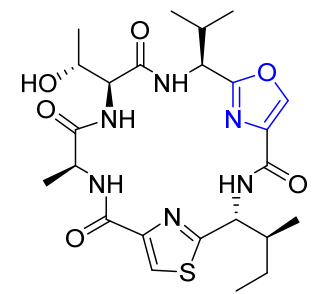

Microcyclamide 7806B (35)

Figure 14. Structures of Microcyclamides.

Other cyclic hexapeptides were subsequently brought to light, such as Microcyclamide 7806A (34) and 7806B (35) (Figure 14), reported by Ziemert et al. in 2008, upon comparing the biosynthetic gene clusters of the organisms M. aeruginosa NIES-298 and M. aeruginosa PCC-7806 [55].

However, in that same year, Portmann et al. published the isolation of Aerucyclamide C (36) and the structural revision of Microcyclamide 7806A (37). Regarding the revised structure of 37, the authors observed that while assigning the structure of Aerucyclamide 36 by NMR, most of the chemical shifts obtained were in line with those studied by Ziemert et al. [55] in the structure of Microcyclamide 7806A (37), the exception being the appearance of a broad signal resonating at $8.28 \mathrm{ppm}$ in the latter. To better understand this mismatch between the structures of $\mathbf{3 4}$ and 36, Portmann et al. analyzed the resulting product, structure 37 , from the acidic treatment of $\mathbf{3 6}$. They concluded that the signal at $8.28 \mathrm{ppm}$ corresponds to the protons of the $\mathrm{NH}_{3}{ }^{+}$group, which results from the oxazoline-ring opening upon acidic hydrolysis. Further evidence to support the existence of the $\mathrm{NH}_{3}{ }^{+}$ 
group was provided by HR-ESIMS data. Finally, the NMR data of 37 were in accordance with those of Microcyclamide 7806A (previously assigned structure 34). This outcome led the authors not only to reassign the original structure of 34 to the revised structure 37, but also to analyze Microcyclamide 7806B (35), furnished from 37 under a sequence of basic and acidic conditions (Scheme 2). Therefore, the structures of $\mathbf{3 5}$ and $\mathbf{3 7}$ are in fact hydrolysis products of $\mathbf{3 6}$, as opposed to being natural products from M. aeruginosa PCC 7806. The observation that 37 and 35 lacked bioactivity in a range of bioassays, including antibacterial activity and others, further demonstrates their synthetic nature, i.e., 35 and 37 are unnatural cyclamides, in contrast to the natural cyclamides that normally show a wide spectrum of biological activity. In this regard, 36 displayed relevant activity against $P$. falciparum $\mathrm{K} 1$, with an $\mathrm{IC}_{50}$ value of $2.3 \mu \mathrm{M}$, and emerges as a promising antimalarial agent [56]. The activity of $36 \mathrm{vs.} \mathrm{the} \mathrm{lack} \mathrm{of}$ activity of $\mathbf{3 5}$ and $\mathbf{3 7}$ reinforces the importance of the heterocycle (oxazoline in this case) for the activity due presumable to the conformational restriction imposed by the cycle.

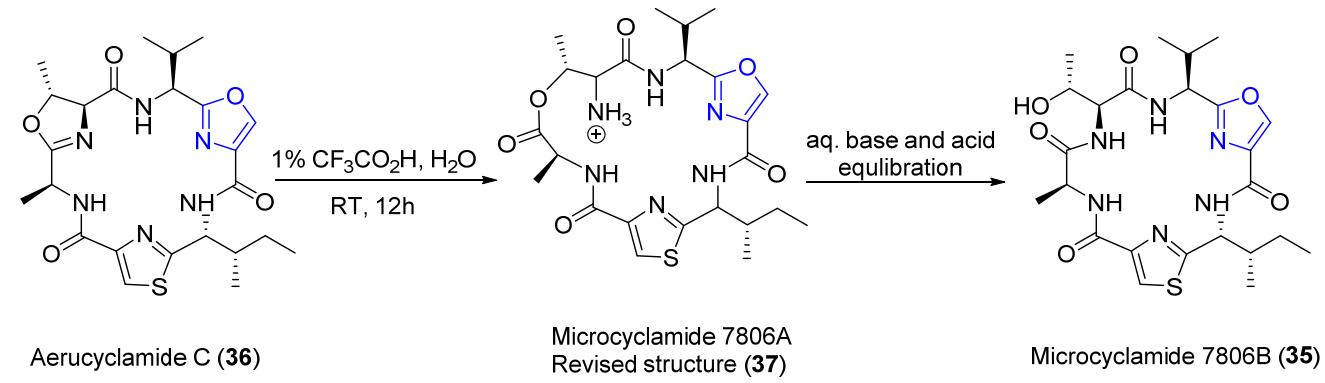

Scheme 2. Acidic and basic hydrolysis of Aerucyclamide 36.

\subsection{Leucamide A}

Leucamide A (38) was first isolated by Kehraus et al. from the marine sponge Leucetta microraphis, collected from the Great Barrier Reef, Australia (Figure 15). The planar structure of 38 was analyzed by spectroscopic techniques, revealing seven amino acids and other amino acid derivatives: Leu, oxazole, Ala, methyloxazole, thiazole, Val, and Pro. Interestingly, the rare mixed 4,2-bisheterocycle tandem pair consists of a methyloxazole subunit and thiazole subunits [10]. The other bioactive peptides, e.g., Microcin B17 (8), show an oxazole linked to thiazole. Moieties like these can be useful pharmacophores in combinatorial libraries since their activity appears to correlate with the location and identity of the tandem pairs [7]. All the amino acids present in 38 show an L-configuration. This compound is cytotoxic towards the HMO2, HepG2, and Huh7 cell lines [10]. No antiviral activity has been reported for 38 [10]; however, its analogue, which contains the 4,2-bisheterocyclic tandem pairs, shows antiviral activity and therefore emerges as a useful scaffold for the synthesis of new antiviral agents [57].

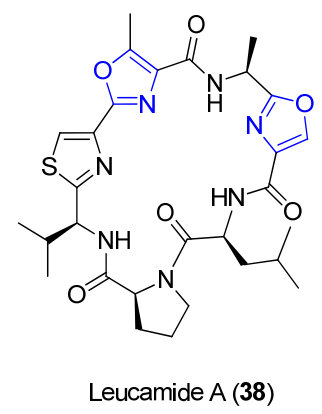

Figure 15. Structure of Leucamide A.

\subsection{YM-216391}

YM-216391 (39) is an unusual polyoxazole-thiazole-based cyclopeptide that was first isolated from Streptomyces nobilis in 2005 by Sohda et al. during the screening of anticancer drugs (Figure 16) [58]. 
The structure of 39 comprises a sequence of five azoles (trisoxazole, a thiazole, and phenyloxazole), originated from Ser, Cys, and Phe, respectively, linked via a Gly-Val-Ile tripeptide tether [58]. Compound 39 shares both the structure and biological homology with Telomestatin [58] a potent telomerase inhibitor isolated from Streptomyces anulatus with promising potential use in cancer chemotherapy. Biological experiments suggest that 39 is cytotoxic towards human cervical cancer HeLa S3 cells and other human cancer cell lines. The OVCAR-3 cell line is more sensitive to 39 than other cell lines, while colon cancer KM-12 and HCT-15 cell lines are more resistant than the other cell lines used in the screening [58].

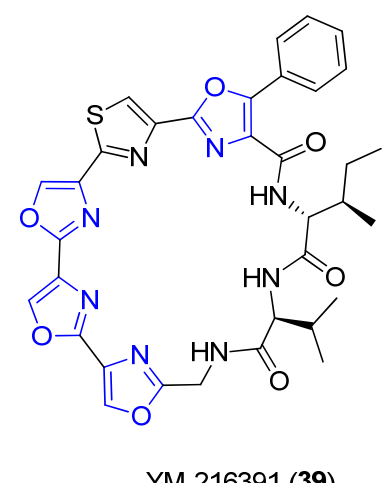

Figure 16. Structure of YM-216391.

\subsection{Urukthapelstatin A}

Urukthapelstatin A (Ustat A) (40) is a unique polyoxazole-thiazole-based cyclic peptide that was discovered by Matsuo et al (Figure 17) [59]. It derives from the Thermoactinomycetaceae family and genus Mechercharimyces asporophorigenens YM11-542 and was detected during a broad screening of antibiotics. The structure of $\mathbf{4 0}$ resembles that of Mechercharmycin 41 and YM-216391 (39), potent cytotoxic compounds isolated from the Thermoactinomycetaceae and Streptomyces, respectively. Showing strong cytotoxicity at the nanomolar range against human cancer cell lines, especially lung and ovarian cancer cell lines, $\mathbf{4 0}$ also displays activity similar to other biologically active drugs currently in use [59].

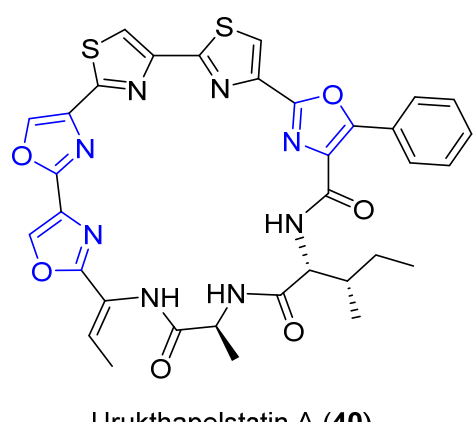

Figure 17. Structure of Urukthapelstatin A.

\subsection{Mechercharmycins $A$ and $B$}

Mechercharmycins A (41) and B (42) were isolated from Thermoactinomyces sp. YM3-251 (Figure 18), collected in Mecherchar in the Republic of Palau (North Pacific Ocean) by Kanoh et al. [60] during the screening of marine microorganisms with antitumor activity. 


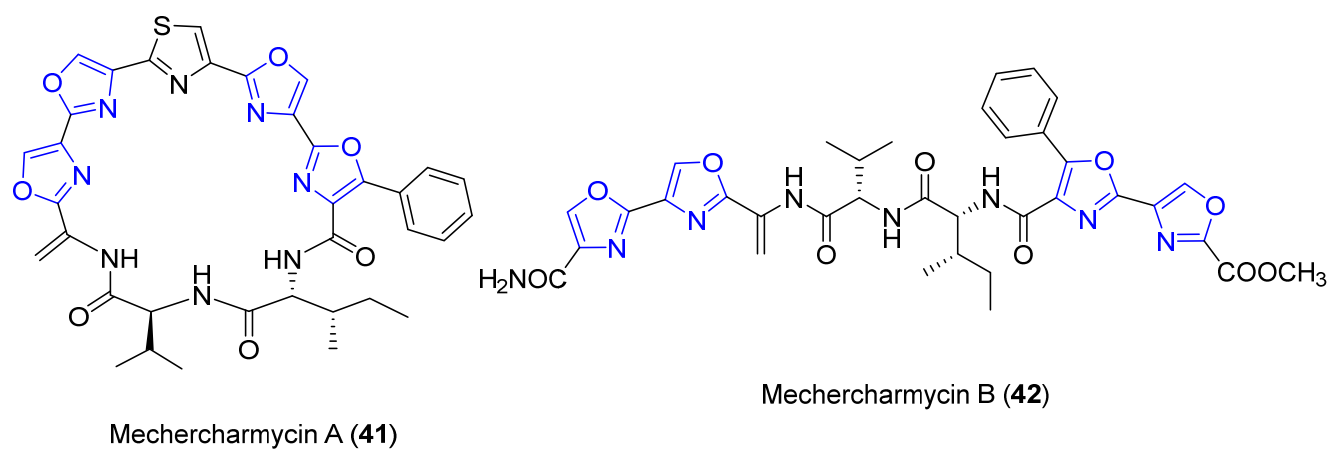

Figure 18. Structures of Mechercharmycin A and B.

X-ray crystallographic studies and 2D NMR revealed that 41 is a macrocycle with a peptidic nature composed of dehydroalanine, Val and Ile, and five continuum azoles (oxazoles and thiazole) [60]. Compound 41 has a similar structure to that of IB-01211 [61] isolated from the closely related marine microorganism strain ES7-008. Inactive against cancer cells, $\mathbf{4 2}$ is a linear congener of the antitumor active 41. This observation may imply that the cyclic nature of $\mathbf{4 1}$ is essential for its antitumor activity. Furthermore, the structure and biological activity of $\mathbf{4 1}$ closely resemble those of the strongly cytotoxic peptides YM-216391 (39) and Ustat A (40) [60].

\subsection{Haliclonamides $A-E$}

Marine sponges were studied to determine whether they contained iron-binding natural compounds. This study was conducted to further understand iron-related biofunctions in living organisms in seawater, since the world's oceans are iron-deficient environments and more than $99 \%$ of dissolved iron in ocean water is bound to organic substances [62-65]. Haliclonamide A (43) and its analogue Haliclonamide B (44) were isolated from the Palauan marine sponge Haliclona sp. by Guan et al. The spectroscopic analysis established that the structures of $\mathbf{4 3}$ and $\mathbf{4 4}$ contain methlyoxazoline and oxazole moieties. The structure of $\mathbf{4 3}$ was determined as a novel cyclic peptide containing oxazole and methyloxazoline rings (Figure 19).
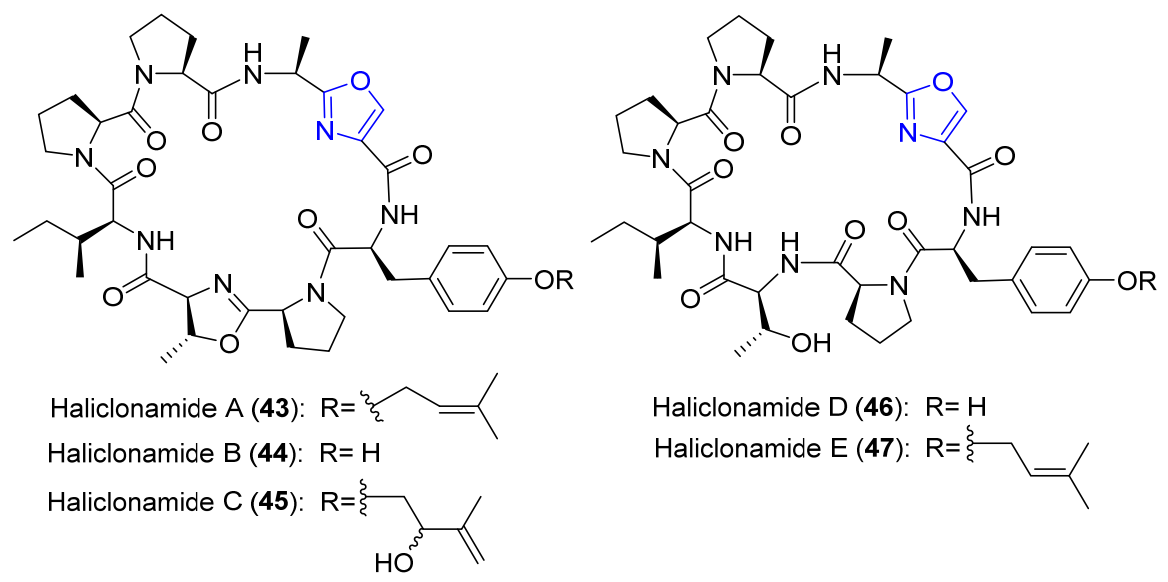

Figure 19. Structures of Haliclonamide A-E.

Peptides $\mathbf{4 3}$ and $\mathbf{4 4}$ form a 1:1 stable complex specifically with trivalent iron $\mathrm{Fe}(\mathrm{III})$ and $\mathrm{Cr}(\mathrm{III})$. However, they fail to form complexes with divalent iron and other cation species such as $\mathrm{Cu}^{2+}, \mathrm{Zn}^{2+}$, $\mathrm{Co}^{2+}, \mathrm{Ni}^{2+}, \mathrm{Al}^{3+}$, or $\mathrm{Ti}^{3+}$. The iron concentration in Haliclona sponge is from 10 to 100 times more concentrated than in other seawater organisms/tissues. This observation suggests that this sponge takes up iron through non-siderophore metal-binding of $\mathbf{4 3}$ and $\mathbf{4 4}$. Other marine organisms may also take up iron in a similar manner [66]. 
Haliclonamides C (45), D (46), and E (47) were isolated from the Palauan marine sponge Haliclona sp. by Sera et al. while searching for new bioactive peptides with antifouling activity [67]. These peptides show antifouling activity towards the blue mussel Mytilus edulis galloprovincialis. These antifouling activities were tested by the foot-stimulating method developed by Hayashi and Miki in 1996 [68]. The structures of $\mathbf{4 5 - 4 7}$ were determined by spectroscopic analysis (Figure 19) [67].

\subsection{Myriastramides A-C}

Myriastramides A-C (48-50) are modified cyclic cynobactin-like octapeptides (Figure 20). They were isolated by Erickson et al. from Myriastra clavosa (Order Astrophorida, Family Ancorinidae), collected in the Philippines. Produced via polyketide biosynthesis, $\mathbf{4 8 - 5 0}$ are unexpectedly biologically inactive, in spite of being isolated from cytotoxic fractions of $M$. clavosa extracts. The structures of 48-50 were elucidated by NMR spectroscopic analyses, as well as by degradation and derivatization studies. The structure of $\mathbf{4 8}$ contains Ile, O-substituted Tyr, Ala, three Pro residues, a prenyl ether moiety, an oxazole, and a methyloxazole ring. Compounds 48 and 49 differ only in the R groups. Myriastramide C (50) was found to be unstable, decomposing upon storage. Its structure has a Trp, two Pro residues, and three Val residues, thiazole and oxazole rings [69]. Importantly, the structures of 48 and 49 show a similar composition to that of the haliclonamides. However, the latter differ regarding the amino acid sequence, $\mathrm{N}$-to-C linkage, and the partial reduction of the methyloxazole present [66]. Compound 48 shows L-stereochemistry at the $\alpha$-position of all the residues, as determined by Marfey's method. The Ile was analyzed by ligand-exchange, a chiral HPLC method, which confirmed the L-Ile configuration [69].
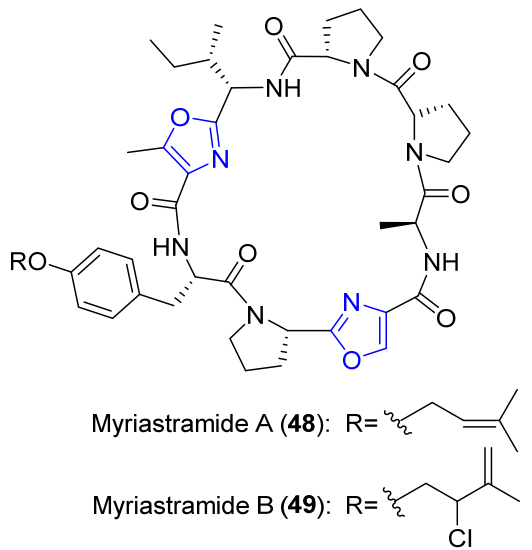

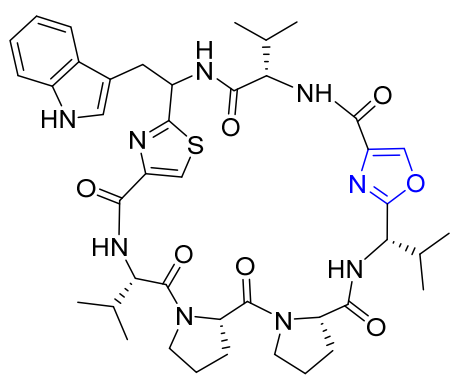

Myriastramide C (50)

Figure 20. Structures of Myriastramide A-C.

\subsection{Wewakazoles}

Wewakazole A (51a) and Wewakazole B (51b) (Figure 21) are cyanobactins that were isolated from Red Sea Moorea producens by Lopez et al. and from a Papua New Guinea collection of Lyngbya majuscula by Nogle et al., respectively $[13,70]$. These two cyclic dodecapeptides contain nine common amino acids and three oxazole rings. The difference between $\mathbf{5 1 a}$ and $\mathbf{5 1 b}$ is that one has an oxazole moiety instead of a methyl oxazole and a Val rather than a second Ala [13]. 51b is more cytotoxic towards numerous cancer cell lines than 51a [13,71,72]. 


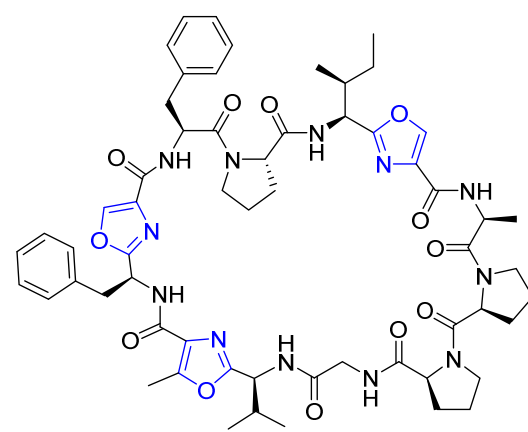

Wewakazole A (51a)

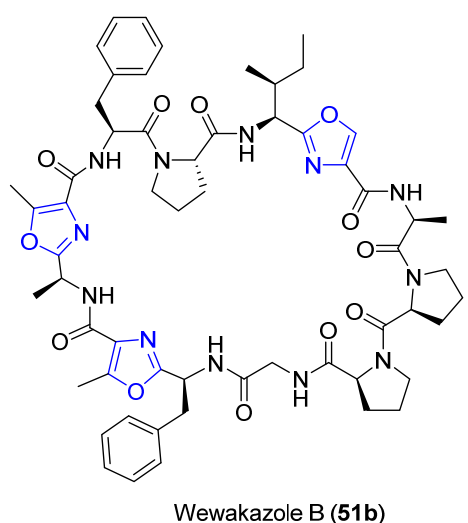

Wewakazole B (51b)

Figure 21. Structures of Wewakazole A and Wewakazole B.

\subsection{Keramamides $B-E$}

The structure of Keramamide B (52) [73] has three non-proteinogenic amino acids—ornithine (Orn), $\alpha$-aminobutyric acid (Aba), and norvaline (nVal) (Figure 22). This compound is a sidechain-to-tail cyclic peptide that features a rare conjugation of three modified amino acid units $(\alpha, \beta$-unsaturated amide functionality, an oxazole ring, and an $\alpha$-keto- $\beta$-amino acid moiety) linked consecutively within the cyclic scaffold. Additionally, the units nVal and Orn are important building blocks in the structure of 52, in that the former is converted into the oxazole ring, while the $\alpha$-NH of the latter bears the side-chain part of the peptide, and the $\delta-\mathrm{NH}$, which is bonded to the carbonyl of the 2-bromo-5-hydroxytryptophan (BhTrp) group, forms part of the macrocyclic peptide backbone. Another uncommon structural characteristic of 52, apart from the $\mathrm{nVal}$ in between the Ile and Orn residues, is the presence of the 2-hydroxy-3-methylpentanoic acid (Hmp) group protecting the N-terminus in the side chain. Moreover, the marine sponge Theonella [73,74], from which 52 was obtained, also furnished Keramamides C-E (53-55), among others lacking the oxazole ring, such as Keramamide A [75]. Although the structures of 52-55 all present identical modified amino acid components, a major difference regards the type of $R^{1}$ and $R^{2}$ substituents. Of the first keramamides isolated, $\mathbf{5 2 - 5 4}$, and tested for the inhibition of superoxides, generated by human neutrophils, all of them displayed biological activity; 55, in turn, showed antitumor activity on L1210 murine leukemia cells and KB human epidermoid carcinoma cells (Figure 22) [74].

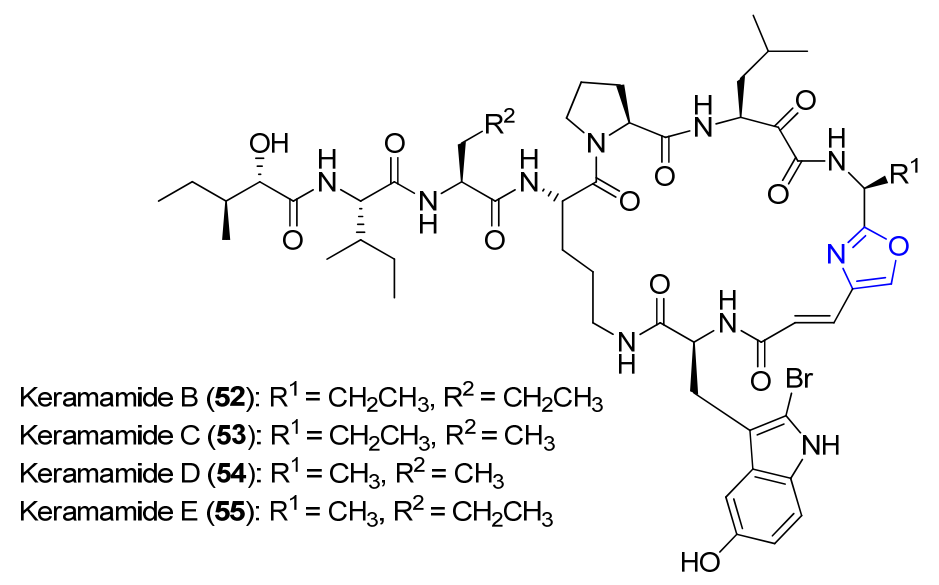

Figure 22. Structures of Keramamide B-E. 


\section{Bicyclic Peptides}

\section{Diazonamides $A-E$}

Diazonamides A and B (56 and 58) were originally isolated by Lindquist et al. from the colonial ascidian Diazona chinensis (revised to Diazona angulata [76]) (Figure 23). Spectroscopic characterization revealed that these compounds had complex structures [77]. In particular, the residues Tyr and Val (linked to the oxazole ring) were found to have an L-configuration, but no definitive stereochemical assignment was provided for $\mathrm{C}-\mathrm{OH}$ in the furan ring or for the terminal Val residue in 56. However, a synthetic program devoted to 56 reassigned the structure of this compound to that of Diazonamide A (57), affording further information on the chemical composition and on the stereochemistry of 57. Other diazonamides C-E (59-61) were studied from the ascidian Diazona angulate [76]. Compounds 57-61 are post-translationally modified peptides, but they also contain three natural amino acids (Val, Trp, and Tyr). The structural complexity and uniqueness of $\mathbf{5 7 - 6 1}$ is highlighted by the presence of chlorinated oxazole as part of the bis-oxazole moiety, the chloroindole unit, and the fragment (b)-fused dihydrobenzofuran-dihydroindole, all merged within a strained double macrocyclic array. The metabolites 59-61 showed moderate cytotoxicity in three human tumor cell lines [76]. Regarding 57 , it was found to be more cytotoxic than 58 [77].

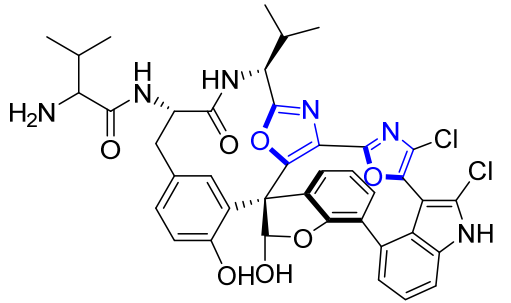

Original structure of Diazonamide A (56)

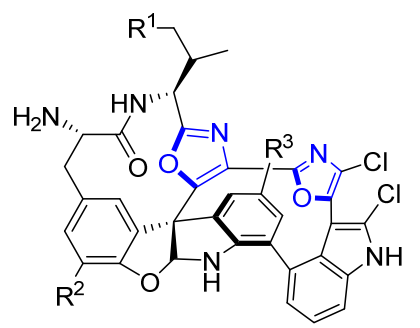

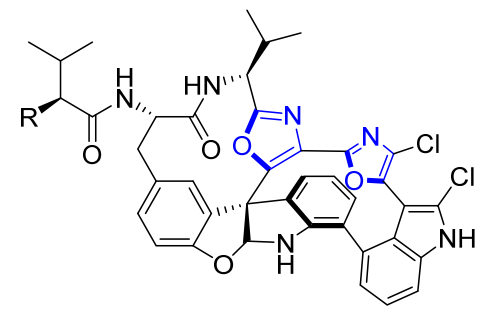

Revised structure of Diazonamide $A(57): \mathrm{R}=\mathrm{OH}$ Diazonamide $\mathrm{C}$ (59): $\mathrm{R}=\mathrm{NH}_{2}$

$$
\begin{aligned}
& \text { Diazonamide B (58): } R^{1}=H, R^{2}=B r, R^{3}=H \\
& \text { Diazonamide D (60): } R^{1}=\mathrm{CH}_{3}, R^{2}=H, R^{3}=C l \\
& \text { Diazonamide E (61): } R^{1}=\mathrm{CH}_{3}, R^{2}=R^{3}=H
\end{aligned}
$$

Figure 23. Structures of Diazonamide A-E.

\section{Thiopeptides}

Thiopeptides are naturally occurring peptides of ribosomal origin. They are characterized by a dehydroamino acid tail, with a central nitrogen-containing 6-membered heterocycle, and several azoles in a macrocyclic array. Most thiopeptides show strong inhibition of protein synthesis in bacteria and share a common mode of action [78].

\subsection{Baringolin}

Baringolin (62) was isolated by a pharmaceutical company, the Instituto Biomar SA (Figure 24), from the marine Micrococcaceae family and bacterium Kucuria sp. MI-67-EC3-038 strain, collected in Alicante, southern Spain [79]. Baringolin 62 is a naturally occurring peptide that belongs to the 
thiopeptide family of $d$ series [80], and it contains a central 2,3,6-trisubstituted pyridine [80]. It is considered a member of the thiopeptide family of antibiotics because of the presence of a dehydroalanine side chain, high sulfur content, and antibacterial activity commonly found in thiopeptide [81].

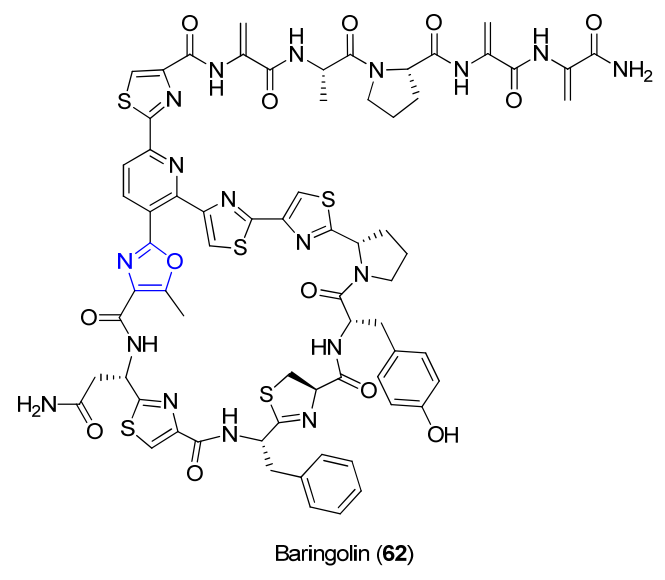

Figure 24. Structure of Baringolin.

The spectroscopic methods used to elucidate the structure of 62 assigned two parts: the pentapeptide and the macrocycle. The macrocycle has three natural amino acids (Tyr, Phe, and Asn), a pyridine, three thiazole rings, a methyloxazole ring, and other structural motifs not present in other thiopeptides, such as a thiazoline with a chiral center and a pyrrolidine motif derived from a Pro residue. Compound 62 also has a long peptidic tail—a pentapeptide with three methylidenes-attached to the pyridine through the fourth thiazole ring. Additionally, the structure of $\mathbf{6 2}$ features the longest tail reported to date in the described family of antibiotics. It also contains seven stereocenters with natural L-configuration. These findings are consistent with the ribosomal origin of $\mathbf{6 2}$. This compound shows good activity against Gram-positive bacteria, including Propionibacterium acnes, Micrococcus luteus, S. aureus, and B. subtilis [79].

Other members of the thiopeptide family, discussed below, include the following natural metabolites: Thioxamycin 63; Thioactin 64; Promothiocins 65 and 66; Sulfomycins 67-69; A10225 (70-72); and Methylsulfomycin 73.

\subsection{Thioxamycin and Thioactin}

Matsumoto et al. isolated Thioxamycin 63 (Figure 25) as an acidic, lipophilic sulfur-containing peptide from the Streptomyces sp. strain PA-46025. No stereochemical information was provided for the thiazole-modified Ala residue [82]. Compound 63 exhibits a wide range of antibacterial activity against anaerobic Gram-positive and Gram-negative bacteria, as well as against aerobic Gram-positive bacteria. With a high sulfur content, 63 is closely related to Sulfomycins 67 and 68 (see below), which show antibiotic properties [82]. Thioactin 64 was also isolated as a derivative of 63 by Yun et al. from Streptomyces sp. strain DP94. Using 1D and 2D NMR spectra, those authors revealed that the structure of 64 contains Thr, two oxazole rings, three thiazole rings, and two dehydroalanines (Figure 25).

Compounds 63 and 64 share similar structural features. However, the C-terminal carboxylic acid of the dehydroalanine side chain in 63 is replaced with an amide group in 64 [83]. 


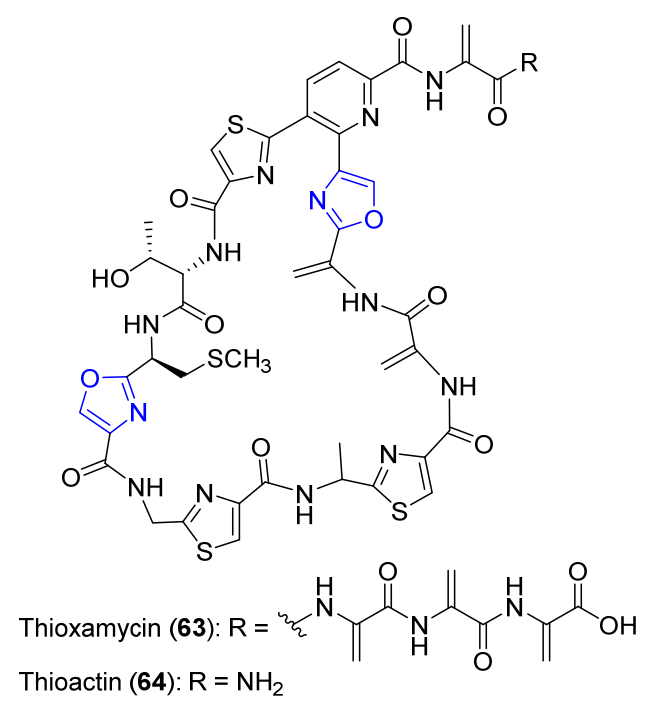

Figure 25. Structures of Thioxamycin and Thioactin.

\subsection{Promothiocins $A$ and $B$}

Promothiocins A (65) and B (66) were isolated from Streptomyces sp. SF2741 by Yun et al. as tipA promoter-inducing substances (Figure 26) [81]. TipA is a regulatory protein that autonomously activates the transcription of its promoter when interacting either with thiostrepton $[84,85]$ or other related thiopeptide antibiotics [86]. By means of 1D and 2D NMR spectra, the planar structures of 65 and 66 were assigned as unique 26-membered thiopeptides composed of Val, Gly, Ala, two methyloxazole rings, two thiazole rings, pyridine, and three dehydroalanines [81]. The absolute stereochemistry of $\mathbf{6 5}$ and $\mathbf{6 6}$ has been examined in degradation studies. The residues Ala and Val were found to have an L-configuration [87].

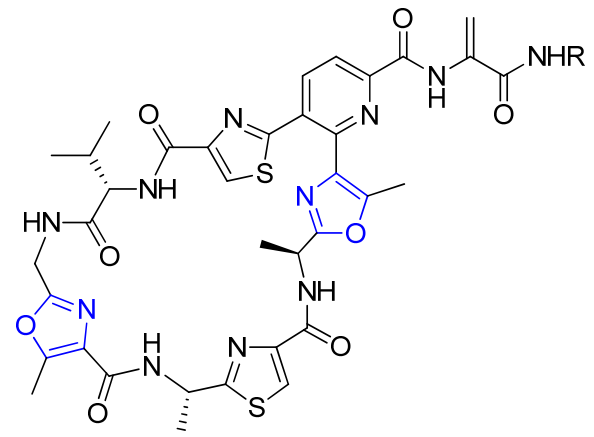

Promothiocin A (65): $\mathrm{R}=\mathrm{H}$

Promothiocin B (66): $\mathrm{R}=\mathrm{C}\left(\mathrm{CH}_{2}\right) \mathrm{CONHC}\left(\mathrm{CH}_{2}\right) \mathrm{CONH}_{2}$

Figure 26. Structures of Promothiocin A and B.

\subsection{Sulfomycins I-III}

Sulfomycins I-III (67-69) were first isolated by Egawa et al. from Streptomyces viridochromogenes MCRL-0368 (Figure 27) [88]. These compounds exhibited antibacterial activity against Gram-positive cocci, bacilli, mycoplasma, and anaerobic bacteria, as well as against those resistant to penicillin, streptomycin, tetracycline, chloramphenicol, and staphylococci freshly isolated from clinical material $[88,89]$. They are weakly active against Neisseria, Bordetella, and mycobacteria. The structures of 67-69 were determined by 1D and 2D NMR spectra. They all contain two thiazole rings, three oxazole rings, four dehydroalanines, Thr and pyridine, and differ only in one of the oxazole units $[89,90]$. In the 
structure of 68, the Thr unit has an L-configuration [89]. Regarding the carbon atom attached to the methoxy group, no stereochemical information was provided.

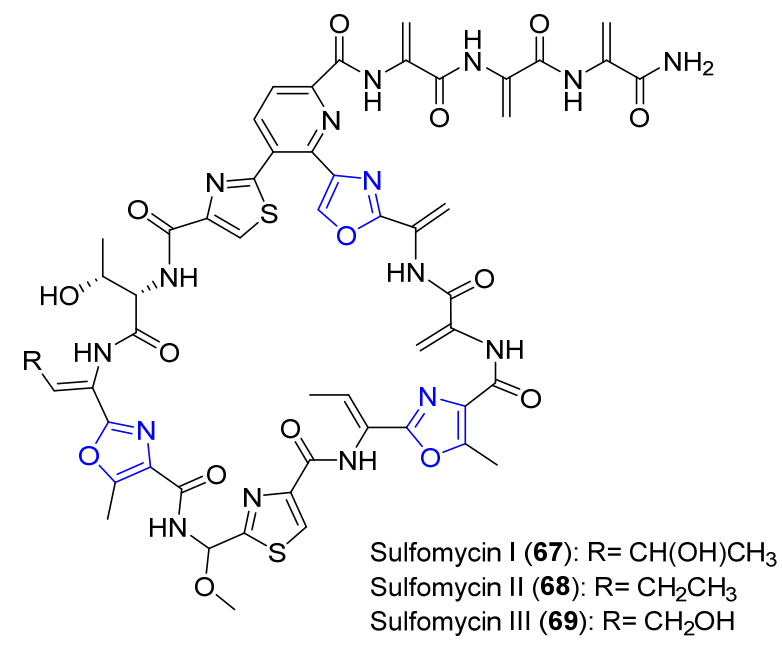

Figure 27. Sctructures of Sulfomycins I, II, and III.

\section{5. $A 10255 B, E$, and $G$}

A10255 is a multicomponent (designated A10255B (70), C, E (71), F, G (72), H, and J) (Figure 28), sulfur-containing complex of antibiotics that was isolated from Streptomyces gardneri NRRL 15,537 by Debono et al. These compounds display strong antimicrobial activity against Gram-positive bacteria and have potential use as growth promoters, and they also prevent lactic acidosis in farm animals. The major components of these antibiotics are A10255B (70) and G (72), which were isolated in sufficient amount to allow the determination of their structures, while the other components were isolated in small amounts. The structures of compounds 70-72 are similar to the highly modified thiopeptide family of antibiotics, e.g., the metabolites Sulfomycin 67, Thioxamycin 63, Berninamycin A [90], Thiopeptin [91], and Thiostrepton [84,85]. A10255 (70-72) share common features with these thiopeptides, such as oxazole/thiazole rings, a pyridine moiety, and several unusual amino acid units, such as dehydrovaline, dehydrobutyrine, and dehydroalanine [92].

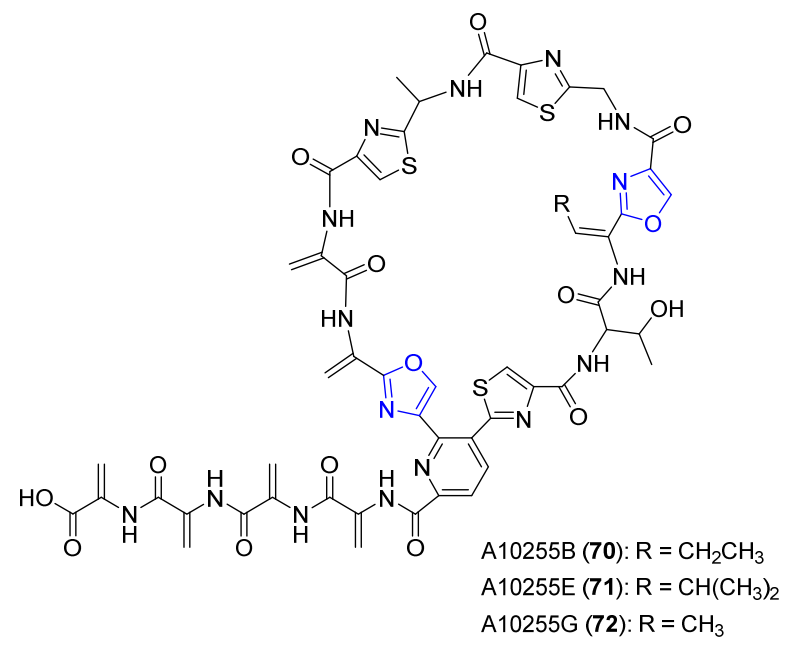

Figure 28. Structures of A10255B, E, and G.

Compounds 70-72 show a similar composition, except for the alkyl substituents at $\mathrm{R}$ located in one of the oxazole-containing moieties. Compound $\mathbf{7 2}$ contains a masked dehydrobutyrine residue (R-methyl group), $\mathbf{7 0}$ has a masked dehydronorvaline residue (R-ethyl group), while $\mathbf{7 1}$ contains a 
masked dehydronorleucine residue (R-isopropyl group) [93]. No stereochemical assignment of the Thr and the masked Ala was provided by the authors.

\subsection{Methylsulfomycin I}

Methylsulfomycin I (73) is a new cyclic peptide antibiotic that was isolated from the fermentation broth of Streptomyces sp. HIL Y-9420704 by Kumar et al. (Figure 29). Compound 73 shows good in vitro activity for a wide range of Gram-positive bacteria, as well as for vancomycin- and teicoplanin-resistant organisms. It was found to be 800 -fold more effective than vancomycin $(>100 \mu \mathrm{g} / \mathrm{mL})$ when tested against vancomycin- and teicoplanin-sensitive and -resistant organisms. Compound 73 decomposes into a practically insoluble biologically inactive compound in most organic solvents commonly used. The structure of 73 was elucidated by NMR and GC-MS. Like other thiopeptides, it contains a macrocyclic core and a dehydro tail, in addition to two thiazole rings, three oxazole rings, a Thr residue with other unidentified units, a pyridine, and four dehydroalanines. The NMR spectral data of this compound are closely related to those reported for other thiopeptides, such as Thioxamycin 63, Berninamycin A [90], and Sulfomycin (I) 67. Compound 73 is similar to Sulfomycin 67 except that it has three 5-methyloxazole rings [94].

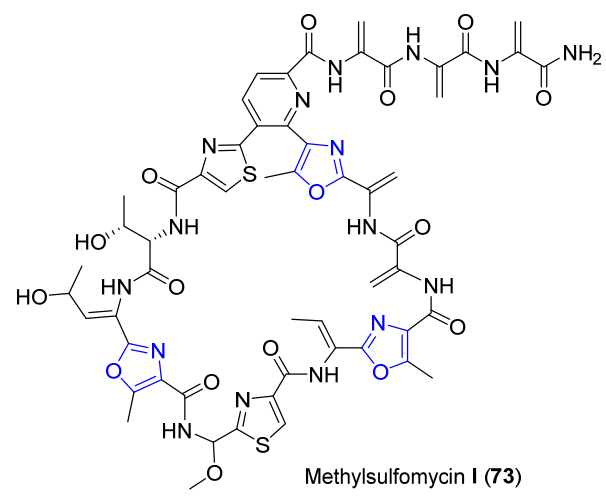

Figure 29. Structure of Methylsulfomycin I.

\section{Overview}

This work provides general information on the isolation, structural elucidation, and possible biological activity shown by natural peptides containing oxazole moieties and highlights the importance of oxazole rings in peptides (see Table 1 for a list of the peptides discussed in this work).

Table 1. Brief information about the source, isolation, bioactivity, and references of oxazole-containing peptides.

\begin{tabular}{|c|c|c|c|c|c|}
\hline Peptide Name & Natural Source & Organism & Bioactivity & Class/Type & References \\
\hline A10225B, G and E & $\begin{array}{l}\text { Colorado soil } \\
\text { bacterium }\end{array}$ & $\begin{array}{l}\text { Streptomyces gardneri } \\
\text { NRRL } 15537\end{array}$ & $\begin{array}{l}\text { Antimicrobial activity, growth } \\
\text { promoter, prevent lactic } \\
\text { acidosis in farm animals }\end{array}$ & Thiopeptides & {$[92,93]$} \\
\hline Aerucyclamides C & Cyanobacterium & $\begin{array}{c}\text { Microcystis aeruginosa } \\
\text { PCC } 7806\end{array}$ & Promising antimalarial agent & Cyclic peptide & [56] \\
\hline Almazoles A-D & $\begin{array}{l}\text { Senegal } \\
\text { seaweed }\end{array}$ & $\begin{array}{c}\text { Genus } \\
\text { Haraldiophyllum }\end{array}$ & $\begin{array}{c}\text { Almazole D: antibacterial } \\
\text { activity }\end{array}$ & $\begin{array}{l}\text { Short linear } \\
\text { peptide }\end{array}$ & [18-22] \\
\hline Baringolin & $\begin{array}{c}\text { Spain } \\
\text { bacterium }\end{array}$ & $\begin{array}{l}\text { Kucuria sp. } \\
\text { MI-67-EC3-038 }\end{array}$ & Antibacterial activity & Thiopeptide & {$[78,79]$} \\
\hline Bistratamides & $\begin{array}{l}\text { Philippine } \\
\text { ascidian }\end{array}$ & Lissoclinum bistratum & $\begin{array}{l}\text { Bistratamide D: } \\
\text { neurodepressant properties } \\
\text { Bistratamides M and N: with } \\
\text { antitumor activity }\end{array}$ & Cyclic peptides & [39-41] \\
\hline
\end{tabular}


Table 1. Cont.

\begin{tabular}{|c|c|c|c|c|c|}
\hline Peptide Name & Natural Source & Organism & Bioactivity & Class/Type & References \\
\hline $\begin{array}{l}\text { Dendroamides } \\
\text { A-C }\end{array}$ & $\begin{array}{c}\text { Terrestrial } \\
\text { blue-green alga }\end{array}$ & $\begin{array}{c}\text { Stigonema } \\
\text { dendroideum }\end{array}$ & $\begin{array}{l}\text { Dendroamide A: potent } \\
\text { MDR-reversing agent }\end{array}$ & Cyclic peptide & [43-45] \\
\hline Diazonamides A-E & $\begin{array}{l}\text { Marine colonial } \\
\text { ascidian }\end{array}$ & Diazona angulata & Cytotoxicity activity & Bicyclic peptide & {$[76,77]$} \\
\hline Dolastatins $\mathrm{E}$ and I & $\begin{array}{l}\text { Japanese sea } \\
\text { hare }\end{array}$ & Dolabella auricularia & Cytotoxicity activity & $\begin{array}{c}\text { Cyclic } \\
\text { hexapeptides }\end{array}$ & {$[49,51]$} \\
\hline Goadsporin & Soil bacterium & $\begin{array}{l}\text { Streptomyces sp. } \\
\text { TP-A0584 }\end{array}$ & Antibacterial activity & $\begin{array}{l}\text { Long linear } \\
\text { peptide }\end{array}$ & {$[37,38]$} \\
\hline $\begin{array}{l}\text { Haliclonamides } \\
\qquad \text { A-E }\end{array}$ & $\begin{array}{l}\text { Palauan marine } \\
\text { sponge }\end{array}$ & Haliclona sp. & $\begin{array}{l}\text { Haliclona A and B: Metal-Iron } \\
\text { uptake } \\
\text { Haliclonamide C-E: } \\
\text { antifouling activity }\end{array}$ & Cyclic peptides & [62-67] \\
\hline Keramamides & $\begin{array}{l}\text { Okinawan } \\
\text { marine sponge }\end{array}$ & Theonella sp. & $\begin{array}{l}\text { Keramamide B-D: inhibits } \\
\text { superoxides } \\
\text { Keramamide E: antitumor } \\
\text { activity }\end{array}$ & Cyclic peptides & [73-75] \\
\hline Leucamide A & $\begin{array}{c}\text { Australian } \\
\text { marine sponge }\end{array}$ & Leucetta microraphis & Cytotoxicity activity & Cyclic peptide & {$[10,57]$} \\
\hline Martefragin A & $\begin{array}{l}\text { Marine Red } \\
\text { algae }\end{array}$ & Martensia fragilis & Inhibit lipid peroxidation & $\begin{array}{l}\text { Short linear } \\
\text { peptides }\end{array}$ & {$[23,24]$} \\
\hline $\begin{array}{l}\text { Mechercharmycins } \\
\text { A and B }\end{array}$ & $\begin{array}{c}\text { Marine } \\
\text { bacterium }\end{array}$ & $\begin{array}{c}\text { Thermoactinomyces sp. } \\
\text { YM3-251 }\end{array}$ & $\begin{array}{l}\text { Mechercharmycins A: } \\
\text { antitumor activity }\end{array}$ & Cyclic peptides & [60] \\
\hline $\begin{array}{l}\text { Methylsulfomycin } \\
\text { I }\end{array}$ & Soil bacterium & $\begin{array}{l}\text { Streptomyces sp. HIL } \\
\text { Y-9420704 }\end{array}$ & Antibacterial activity & Thiopeptide & [94] \\
\hline $\begin{array}{l}\text { Microcyclamides } \\
7806 \mathrm{~A} \text { and B }\end{array}$ & Cyanobacterium & $\begin{array}{l}\text { Microcystis aeruginosa } \\
\text { NIES-298 and } \\
\text { PCC-7806 }\end{array}$ & $\begin{array}{l}\text { Microcyclamide: Cytotoxicity } \\
\text { activity }\end{array}$ & Cyclic peptides & {$[54,55]$} \\
\hline Microcin B17 & Soil bacterium & Escherichia coli & Poison DNA gyrase & $\begin{array}{l}\text { Long linear } \\
\text { peptide }\end{array}$ & [29-34] \\
\hline Muscoride A & Cyanobacterium & Nostoc muscorum & Antibacterial activity & $\begin{array}{l}\text { Short linear } \\
\text { peptide }\end{array}$ & [25-28] \\
\hline Myriastramides & Cyanobacterium & Myriastra clavosa & $\begin{array}{l}\text { No biological activity } \\
\text { mentioned on literature }\end{array}$ & Cyclic peptides & [69] \\
\hline $\begin{array}{l}\text { Nostocyclamide, } \\
\text { Nostocyclamide M }\end{array}$ & Cyanobacterium & Nostoc 31 & $\begin{array}{l}\text { Both have cyanobacterial and } \\
\text { allelopathic activity } \\
\text { Nostocyclamide M: anti-algal } \\
\text { activity }\end{array}$ & Cyclic peptides & {$[12,47]$} \\
\hline $\begin{array}{l}\text { Plantazolicins A } \\
\text { and B }\end{array}$ & Soil bacterium & $\begin{array}{c}\text { Bacillus } \\
\text { amyloliquifaciens } \\
\text { FZB42 }\end{array}$ & $\begin{array}{l}\text { Plantazolicin A: Antibacterial } \\
\text { activity }\end{array}$ & $\begin{array}{l}\text { Long linear } \\
\text { peptides }\end{array}$ & [34-36] \\
\hline $\begin{array}{l}\text { Promothiocins A } \\
\text { and B }\end{array}$ & Soil bacterium & $\begin{array}{l}\text { Streptomyces sp. } \\
\text { SF2741 }\end{array}$ & Not reported in literature & Thiopeptide & {$[81,87]$} \\
\hline $\begin{array}{c}\text { Raocyclamides A } \\
\text { and B }\end{array}$ & Cyanobacterium & Oscillatoria raoi & $\begin{array}{c}\text { Raocyclamide A: Cytotoxicity } \\
\text { activity }\end{array}$ & Cyclic peptide & {$[52,53]$} \\
\hline Sulfomycins I-III & Soil bacterium & $\begin{array}{c}\text { Streptomyces } \\
\text { viridochromogenes } \\
\text { MCRL-0368 }\end{array}$ & Antibacterial activity & Thiopeptide & [88-90] \\
\hline $\begin{array}{l}\text { Tenuecyclamides } \\
\text { A-D }\end{array}$ & Cyanobacterium & $\begin{array}{l}\text { Nostoc spongiaeforme } \\
\text { var. tenue Rao }\end{array}$ & $\begin{array}{l}\text { Antimicrobial and cytotoxicity } \\
\text { activity }\end{array}$ & Cyclic peptides & [48] \\
\hline $\begin{array}{l}\text { Thioxamycin and } \\
\text { Thioactin }\end{array}$ & Soil bacterium & $\begin{array}{l}\text { Streptomyces sp. } \\
\text { strain PA-46025 }\end{array}$ & Antibacterial activity & Thiopeptide & {$[82,83]$} \\
\hline Urukthapelstatin A & $\begin{array}{c}\text { Marine } \\
\text { bacterium }\end{array}$ & $\begin{array}{l}\text { Mechercharimyces } \\
\text { asporophorigenens } \\
\text { YM11-542 }\end{array}$ & Cytotoxicity activity & Cyclic peptide & [59] \\
\hline $\begin{array}{l}\text { Venturamides A } \\
\text { and B }\end{array}$ & Cyanobacterium & Oscillatoria sp. & Antimalarial activity & Cyclic peptides & [11] \\
\hline $\begin{array}{l}\text { Wewakazole A and } \\
\text { B }\end{array}$ & Cyanobacterium & $\begin{array}{l}\text { Lyngbya majuscula, } \\
\text { Moorea producens }\end{array}$ & Cytotoxicity activity & Cyclic peptides & {$[13,71,72]$} \\
\hline YM-216391 & Soil bacterium & Streptomyces nobilis & Cytotoxicity activity & Cyclic peptide & [58] \\
\hline
\end{tabular}


The marine environment is home to various species, such as algae, sponges, and cyanobacteria, which naturally synthesize unique bioactive oxazole-containing peptides. Overall, these oxazoles range from short linear peptides to long and complex structures. Other organisms produce cyclic peptides, bicyclic peptides, and even the so-called thiopeptides. Oxazoles and thiazoles form part of the macrocyclic structures of these three classes of peptides, which also contain a pyridine moiety in the case of thiopeptides.

Finally, this work reaffirms the marine environment as a rich source of new compounds with biological properties of interest-compounds expected to find application in the design of novel drugs in the near future.

Author Contributions: The work was conceptualized and supervised by B.G.d.1.T. and F.A. The data and first draft were collected and prepared by J.T.M. and E.B. All authors have read and agreed to the published version of the manuscript.

Funding: This study was funded in part by the following: the National Research Foundation (NRF), Moses Kotane Institute (South Africa); MINECO, (RTI2018-093831-B-100), and the Generalitat de Catalunya (2017 SGR 1439) (Spain).

Acknowledgments: We would like to thank the University of KwaZulu-Natal for encouraging this kind of work.

Conflicts of Interest: The authors declare no conflict of interest.

\section{References}

1. Sun, L. Peptide-based drug development. Mod. Chem. Appl. 2013, 1, 1-2. [CrossRef]

2. Fosgerau, K.; Hoffmann, T. Peptide therapeutics: Current status and future directions. Drug Discov. Today 2015, 20, 122-128. [CrossRef] [PubMed]

3. Vlieghe, P.; Lisowski, V.; Martinez, J.; Khrestchatisky, M. Synthetic therapeutic peptides: Science and market. Drug Discov. Today 2010, 15, 40-56. [CrossRef] [PubMed]

4. Craik, D.J.; Fairlie, D.P.; Liras, S.; Price, D. The future of peptide-based drugs. Chem. Biol. Drug Des. 2013, 81, 136-147. [CrossRef]

5. Murru, S.; Dooley, C.T.; Nefzi, A. Parallel synthesis of bis-oxazole peptidomimetics. Tetrahedron Lett. 2013, 54, 7062-7064. [CrossRef]

6. Pelay-Gimeno, M.; Glas, A.; Koch, O.; Grossmann, T.N. Structure-based design of inhibitors of protein-protein interactions: Nimicking peptide binding epitopes. Angew. Chem. Int. Ed. 2015, 54, 8896-8927. [CrossRef]

7. Roy, R.S.; Kelleher, N.L.; Milne, J.C.; Walsh, C.T. In vivo processing and antibiotic activity of microcin B17 analogs with varying ring content and altered bisheterocyclic sites. Chem. Biol. 1999, 6, 305-318. [CrossRef]

8. Oku, N.; Adachi, K.; Matsuda, S.; Kasai, H.; Takatsuki, A.; Shizuri, Y. Ariakemicins A and B, novel polyketide-peptide antibiotics from a marine gliding bacterium of the genus Rapidithrix. Org. Lett. 2008, 10, 2481-2484. [CrossRef]

9. Wada, H.; Williams, H.E.; Moody, C.J. Total synthesis of the posttranslationally modified polyazole peptide antibiotic plantazolicin A. Angew. Chem. Int. Ed. 2015, 54, 15147-15151. [CrossRef]

10. Kehraus, S.; König, G.M.; Wright, A.D.; Woerheide, G. Leucamide A: A new cytotoxic heptapeptide from the Australian sponge Leucetta microraphis. J. Org. Chem. 2002, 67, 4989-4992. [CrossRef]

11. Linington, R.G.; González, J.; Urena, L.-D.; Romero, L.I.; Ortega-Barría, E.; Gerwick, W.H. Venturamides A and B: Antimalarial constituents of the panamanian marine Cyanobacterium Oscillatoria sp. J. Nat. Prod. 2007, 70, 397-401. [CrossRef] [PubMed]

12. Todorova, A.K.; Juettner, F.; Linden, A.; Pluess, T.; von Philipsborn, W. Nostocyclamide: A new macrocyclic, thiazole-containing allelochemical from Nostoc sp. 31 (cyanobacteria). J. Org. Chem. 1995, 60, 7891-7895. [CrossRef]

13. Lopez, J.A.V.; Al-Lihaibi, S.S.; Alarif, W.M.; Abdel-Lateff, A.; Nogata, Y.; Washio, K.; Morikawa, M.; Okino, T. Wewakazole B, a cytotoxic cyanobactin from the Cyanobacterium Moorea producens collected in the Red sea. J. Nat. Prod. 2016, 79, 1213-1218. [CrossRef] [PubMed]

14. Smolyar, I.V.; Yudin, A.K.; Nenajdenko, V.G. Heteroaryl rings in peptide macrocycles. Chem. Rev. 2019, 119, 10032-10240. [CrossRef] [PubMed] 
15. Turchi, I.J. Oxazole chemistry. A review of recent advances. Ind. Eng. Chem. Prod. Res. Dev. 1981, 20, 32-76. [CrossRef]

16. Tilvi, S.; Singh, K.S. Synthesis of oxazole, oxazoline and isoxazoline derived marine natural products: A review. Curr. Org. Chem. 2016, 20, 898-929. [CrossRef]

17. Joshi, S.; Bisht, A.S.; Juyal, D. Systematic scientific study of 1, 3-oxazole derivatives as a useful lead for pharmaceuticals: A review. Pharma Innov. J. 2017, 6, 109-117.

18. N’Diaye, I.; Guella, G.; Chiasera, G.; Mancini, I.; Pietra, F. Almazole A and almazole B, unusual marine alkaloids of an unidentified red seaweed of the family delesseriaceae from the coasts of Senegal. Tetrahedron Lett. 1994, 35, 4827-4830. [CrossRef]

19. N'Diaye, I.; Guella, G.; Mancini, I.; Pietra, F. Almazole D, a new type of antibacterial 2, 5-disubstituted oxazolic dipeptide from a red alga of the coast of Senegal. Tetrahedron Lett. 1996, 37, 3049-3050. [CrossRef]

20. Guella, G.; Mancini, I.; Pietra, F. Almazole C, a new indole alkaloid bearing an unusually 2, 5-disubstituted oxazole moiety, and its putative biogenetic peptidic precursors, from a senegalese delesseriacean seaweed. Helv. Chim. Acta 1994, 77, 1999-2006. [CrossRef]

21. Miyake, F.; Hashimoto, M.; Tonsiengsom, S.; Yakushijin, K.; Horne, D.A. Synthesis of 5-(3-indolyl) oxazole natural products. Structure revision of Almazole D. Tetrahedron 2010, 66, 4888-4893. [CrossRef]

22. Lade, D.M.; Krishna, V.S.; Sriram, D.; Rode, H.B. A Facile synthesis and antituberculosis properties of almazole D and its enantiomer. ChemistrySelect 2017, 2, 1250-1252. [CrossRef]

23. Takahashi, S.; Matsunaga, T.; Hasegawa, C.; Saito, H.; Fujita, D.; Kiuchi, F.; Tsuda, Y. Martefragin A, a novel indole alkaloid isolated from red alga, inhibits lipid peroxidation. Chem. Pharm. Bull 1998, 46, 1527-1529. [CrossRef]

24. Nishida, A.; Fuwa, M.; Fujikawa, Y.; Nakahata, E.; Furuno, A.; Nakagawa, M. First total synthesis of martefragin A, a potent inhibitor of lipid peroxidation isolated from sea alga. Tetrahedron Lett. 1998, 39, 5983-5986. [CrossRef]

25. Nagatsu, A.; Kajitani, H.; Sakakibara, J. Muscoride A: A new oxazole peptide alkaloid from freshwater cyanobacterium Nostoc muscorum. Tetrahedron Lett. 1995, 36, 4097-4100. [CrossRef]

26. Muir, J.C. Total synthesis of (-)-muscoride A: A novel bis-oxazole based alkaloid from the Cyanobacterium Nostoc muscorum. Synthesis 1998, 1998, 613-618. [CrossRef]

27. Coqueron, P.Y.; Didier, C.; Ciufolini, M.A. Iterative oxazole assembly via $\alpha$-chloroglycinates: Total synthesis of (-)-muscoride A. Angew. Chem. Int. Ed. 2003, 42, 1411-1414. [CrossRef]

28. Wipf, P.; Venkatraman, S. Total synthesis of (-)-muscoride A. J. Org. Chem. 1996, 61, 6517-6522. [CrossRef]

29. Asensio, C.; Pérez-Díaz, J.C.; Martínez, M.C.; Baquero, F. A new family of low molecular weight antibiotics from enterobacteria. Biochem. Biophys. Res. Commun. 1976, 69, 7-14. [CrossRef]

30. Yorgey, P.; Lee, J.; Kördel, J.; Vivas, E.; Warner, P.; Jebaratnam, D.; Kolter, R. Posttranslational modifications in microcin B17 define an additional class of DNA gyrase inhibitor. Proc. Nati. Acad. Sci. USA 1994, 91, 4519-4523. [CrossRef]

31. Thompson, R.E.; Jolliffe, K.A.; Payne, R.J. Total synthesis of microcin B17 via a fragment condensation approach. Org. Lett. 2011, 13, 680-683. [CrossRef] [PubMed]

32. Videnov, G.; Kaiser, D.; Brooks, M.; Jung, G. Synthesis of the DNA gyrase inhibitor microcin B17, a 43-peptide antibiotic with eight aromatic heterocycles in its backbone. Angew. Chem. Int. Ed. 1996, 35, 1506-1508. [CrossRef]

33. Li, Y.-M.; Milne, J.C.; Madison, L.L.; Kolter, R.; Walsh, C.T. From peptide precursors to oxazole and thiazole-containing peptide antibiotics: Microcin B17 synthase. Science 1996, 274, 1188-1193. [CrossRef] [PubMed]

34. Scholz, R.; Molohon, K.J.; Nachtigall, J.; Vater, J.; Markley, A.L.; Süssmuth, R.D.; Mitchell, D.A.; Borriss, R. Plantazolicin, a novel microcin B17/streptolysin S-like natural product from Bacillus amyloliquefaciens FZB42. J. Bacteriol. 2011, 193, 215-224. [CrossRef]

35. Molohon, K.J.; Melby, J.O.; Lee, J.; Evans, B.S.; Dunbar, K.L.; Bumpus, S.B.; Kelleher, N.L.; Mitchell, D.A. Structure determination and interception of biosynthetic intermediates for the plantazolicin class of highly discriminating antibiotics. ACS Chem. Biol. 2011, 6, 1307-1313. [CrossRef]

36. Kalyon, B.; Helaly, S.E.; Scholz, R.; Nachtigall, J.; Vater, J.; Borriss, R.; Süssmuth, R.D. Plantazolicin A and B: Structure elucidation of ribosomally synthesized thiazole/oxazole peptides from Bacillus amyloliquefaciens FZB42. Org. Lett. 2011, 13, 2996-2999. [CrossRef] 
37. Ozaki, T.; Kurokawa, Y.; Hayashi, S.; Oku, N.; Asamizu, S.; Igarashi, Y.; Onaka, H. Insights into the biosynthesis of dehydroalanines in goadsporin. ChemBioChem 2016, 17, 218-223. [CrossRef]

38. Onaka, H.; Tabata, H.; Igarashi, Y.; Sato, Y.; Furumai, T. Goadsporin, a chemical substance which promotes secondary metabolism and morphogenesis in streptomycetes. J. Antibiot. 2001, 54, 1036-1044. [CrossRef]

39. Perez, L.J.; Faulkner, D.J. Bistratamides E- J, Modified cyclic hexapeptides from the Philippines Ascidian Lissoclinum bistratum. J. Nat. Prod. 2003, 66, 247-250. [CrossRef]

40. Urda, C.; Fernández, R.; Rodríguez, J.; Pérez, M.; Jiménez, C.; Cuevas, C. Bistratamides M and N, oxazole-thiazole containing cyclic hexapeptides isolated from Lissoclinum bistratum interaction of zinc (II) with bistratamide K. Mar. Drugs 2017, 15, 209. [CrossRef]

41. Foster, M.P.; Concepcion, G.P.; Caraan, G.B.; Ireland, C.M. Bistratamides C and D. Two new oxazole-containing cyclic hexapeptides isolated from a Philippine Lissoclinum bistratum ascidian. J. Org. Chem. 1992, 57, 6671-6675. [CrossRef]

42. Prinsep, M.R.; Moore, R.E.; Levine, I.A.; Patterson, G.M. Westiellamide, a bistratamide-related cyclic peptide from the blue-green alga Westiellopsis prolifica. J. Nat. Prod. 1992, 55, 140-142. [CrossRef] [PubMed]

43. Ogino, J.; Moore, R.E.; Patterson, G.M.; Smith, C.D. Dendroamides, new cyclic hexapeptides from a blue-green alga. Multidrug-resistance reversing activity of dendroamide A. J. Nat. Prod. 1996, 59, 581-586. [CrossRef] [PubMed]

44. Xia, Z.; Smith, C.D. Total synthesis of dendroamide A, a novel cyclic peptide that reverses multiple drug resistance. J. Org. Chem. 2001, 66, 3459-3466. [CrossRef] [PubMed]

45. Bertram, A.; Pattenden, G. Dendroamide A, nostocyclamide and related cyclopeptides from cyanobacteria. Total synthesis, together with organised and metal-templated assembly from oxazole and thiazole-based amino acids. Heterocycles 2002, 58, 521-561. [CrossRef]

46. Bertram, A.; Pattenden, G. Self-assembly of amino acid-based thiazoles and oxazoles. Total synthesis of dendroamide A, a cyclic hexapeptide from the cyanobacterium Stigonema dendroideum. Synlett 2000, 2000, 1519-1521. [CrossRef]

47. Jüttner, F.; Todorova, A.K.; Walch, N.; von Philipsborn, W. Nostocyclamide M: A cyanobacterial cyclic peptide with allelopathic activity from Nostoc 31. Phytochemistry 2001, 57, 613-619. [CrossRef]

48. Banker, R.; Carmeli, S. Tenuecyclamides A- D, Cyclic Hexapeptides from the Cyanobacterium Nostoc spongiaeforme var. tenue. J. Nat. Prod. 1998, 61, 1248-1251. [CrossRef]

49. Ojika, M.; Nemoto, T.; Nakamura, M.; Yamada, K. Dolastatin E, a new cyclic hexapeptide isolated from the sea hare Dolabella auricularia. Tetrahedron Lett. 1995, 36, 5057-5058. [CrossRef]

50. Sone, H.; Kigoshi, H.; Yamada, K. Isolation and stereostructure of dolastatin I, a cytotoxic cyclic hexapeptide from the Japanese sea hare Dolabella auricularia. Tetrahedron 1997, 53, 8149-8154. [CrossRef]

51. Nakamura, M.; Shibata, T.; Nakane, K.; Nemoto, T.; Ojika, M.; Yamada, K. Stereochemistry and total synthesis of dolastatin E. Tetrahedron Lett. 1995, 36, 5059-5062. [CrossRef]

52. Admi, V.; Afek, U.; Carmeli, S. Raocyclamides A and B, novel cyclic hexapeptides isolated from the cyanobacterium Oscillatoria raoi. J. Nat. Prod. 1996, 59, 396-399. [CrossRef]

53. Freeman, D.J.; Pattenden, G. Total synthesis and assignment of stereochemistry of raocyclamide cyclopeptides from cyanobacterium Oscillatoria raoi. Tetrahedron Lett. 1998, 39, 3251-3254. [CrossRef]

54. Ishida, K.; Nakagawa, H.; Murakami, M. Microcyclamide, a Cytotoxic Cyclic Hexapeptide from the Cyanobacterium Microcystis aeruginosa. J. Nat. Prod. 2000, 63, 1315-1317. [CrossRef] [PubMed]

55. Ziemert, N.; Ishida, K.; Quillardet, P.; Bouchier, C.; Hertweck, C.; de Marsac, N.T.; Dittmann, E. Microcyclamide biosynthesis in two strains of Microcystis aeruginosa: From structure to genes and vice versa. Appl. Environ. Microbiol. 2008, 74, 1791-1797. [CrossRef] [PubMed]

56. Portmann, C.; Blom, J.F.; Gademann, K.; Jüttner, F. Aerucyclamides A and B: Isolation and synthesis of toxic ribosomal heterocyclic peptides from the cyanobacterium Microcystis aeruginosa PCC 7806. J. Nat. Prod. 2008, 71, 1193-1196. [CrossRef] [PubMed]

57. Wang, W.-L.; Yao, D.-Y.; Gu, M.; Fan, M.-Z.; Li, J.-Y.; Xing, Y.-C.; Nan, F.-J. Synthesis and biological evaluation of novel bisheterocycle-containing compounds as potential anti-influenza virus agents. Bioorg. Med. Chem. Lett. 2005, 15, 5284-5287. [CrossRef]

58. Sohda, K.-Y.; Hiramoto, M.; Suzumura, K.-I.; Takebayashi, Y.; Suzuki, K.-I.; Tanaka, A. YM-216391, a novel cytotoxic cyclic peptide from Streptomyces nobilis. J. Antibiot. 2005, 58, 32. [CrossRef] 
59. Matsuo, Y.; Kanoh, K.; Yamori, T.; Kasai, H.; Katsuta, A.; Adachi, K.; Shin-Ya, K.; Shizuri, Y. Urukthapelstatin A, a novel cytotoxic substance from marine-derived Mechercharimyces asporophorigenens YM11-542. J. Antibiot. 2007, 60, 251. [CrossRef]

60. Kanoh, K.; Matsuo, Y.; Adachi, K.; Imagawa, H.; Nishizawa, M.; Shizuri, Y. Mechercharmycins A and B, cytotoxic substances from marine-derived Thermoactinomyces sp. YM3-251. J. Antibiot. 2005, 58, 289. [CrossRef]

61. Hernández, D.; Vilar, G.; Riego, E.; Canedo, L.M.; Cuevas, C.; Albericio, F.; Álvarez, M. Synthesis of IB-01211, a cyclic peptide containing 2, 4-concatenated thia-and oxazoles, via Hantzsch macrocyclization. Org. Lett. 2007, 9, 809-811. [CrossRef] [PubMed]

62. Rue, E.L.; Bruland, K.W. Complexation of iron (III) by natural organic ligands in the Central North Pacific as determined by a new competitive ligand equilibration/adsorptive cathodic stripping voltammetric method. Mar. Chem. 1995, 50, 117-138. [CrossRef]

63. Wu, J.; Luther, G.W., III. Complexation of Fe (III) by natural organic ligands in the Northwest Atlantic Ocean by a competitive ligand equilibration method and a kinetic approach. Mar. Chem. 1995, 50, 159-177. [CrossRef]

64. Witter, A.E.; Luther, G.W., III. Variation in Fe-organic complexation with depth in the Northwestern Atlantic Ocean as determined using a kinetic approach. Mar. Chem. 1998, 62, 241-258. [CrossRef]

65. Price, N.M.; Morel, F.M. Biological cycling of iron in the ocean. In Metal Ions in Biological Systems; Sigel, A., Sigel, H., Eds.; Marcel Dekker, Inc.: New York, NY, USA, 1998; Volume 35, pp. 1-36.

66. Guan, L.L.; Sera, Y.; Adachi, K.; Nishida, F.; Shizuri, Y. Isolation and evaluation of nonsiderophore cyclic peptides from marine sponges. Biochem. Biophys. Res. Commun. 2001, 283, 976-981. [CrossRef]

67. Sera, Y.; Adachi, K.; Fujii, K.; Shizuri, Y. Isolation of Haliclonamides: New peptides as antifouling substances from a marine sponge species. Haliclona. Mar. Biotechnol. 2002, 4, 441-446. [CrossRef]

68. Hayashi, Y.; Miki, W. A newly developed bioassay system for antifouling substances using the blue mussel, Mytilus edulis galloprovincialis. J. Mar. Biotechnol. 1996, 4, 127-130.

69. Erickson, K.L.; Gustafson, K.R.; Milanowski, D.J.; Pannell, L.K.; Klose, J.R.; Boyd, M.R. Myriastramides A-C, new modified cyclic peptides from the Philippines marine sponge Myriastra clavosa. Tetrahedron 2003, 59, 10231-10238. [CrossRef]

70. Nogle, L.M.; Marquez, B.L.; Gerwick, W.H. Wewakazole, a novel cyclic dodecapeptide from a Papua New Guinea Lyngbya majuscula. Org. Lett. 2003, 5, 3-6. [CrossRef]

71. Long, B.; Zhang, J.; Wang, X.; Tang, X.; Wu, Z. Total synthesis and biological evaluation of Wewakazole. Chem. Res. Chin. Univ. 2017, 1-5. [CrossRef]

72. Malloy, K.L.; Villa, F.A.; Engene, N.; Matainaho, T.; Gerwick, L.; Gerwick, W.H. Malyngamide 2, an oxidized lipopeptide with nitric oxide inhibiting activity from a Papua New Guinea marine cyanobacterium. J. Nat. Prod. 2011, 74, 95-98. [CrossRef] [PubMed]

73. Kobayashi, J.; Itagaki, F.; Shigemori, H.; Ishibashi, M.; Takahashi, K.; Ogura, M.; Nagasawa, S.; Nakamura, T.; Hirota, H. Keramamides B. apprx. D, novel peptides from the Okinawan marine sponge Theonella sp. J. Am. Chem. Soc. 1991, 113, 7812-7813. [CrossRef]

74. Kobayashi, J.I.; Itagaki, F.; Shigemori, I.; Takao, T.; Shimonishi, Y. Keramamides E, G, H, and J, new cyclic peptides containing an oxazole or a thiazole ring from a Theonella sponge. Tetrahedron 1995, 51, 2525-2532. [CrossRef]

75. Kobayashi, J.I.; Sato, M.; Ishibashi, M.; Shigemori, H.; Nakamura, T.; Ohizumi, Y. Keramamide A, a novel peptide from the Okinawan marine sponge Theonella sp. J. Chem. Soc. Perkin Trans. 1991, 1, 2609-2611. [CrossRef]

76. Fernández, R.; Martin, M.J.; Rodríguez-Acebes, R.; Reyes, F.; Francesch, A.; Cuevas, C. Diazonamides C-E, new cytotoxic metabolites from the ascidian Diazona sp. Tetrahedron Lett. 2008, 49, 2283-2285. [CrossRef]

77. Lindquist, N.; Fenical, W.; Van Duyne, G.D.; Clardy, J. Isolation and structure determination of diazonamides $\mathrm{A}$ and $\mathrm{B}$, unusual cytotoxic metabolites from the marine ascidian Diazona chinensis. J. Am. Chem. Soc. 1991, 113, 2303-2304. [CrossRef]

78. Just-Baringo, X.; Bruno, P.; Pitart, C.; Vila, J.; Albericio, F.; Álvarez, M. Dissecting the structure of thiopeptides: Assessment of thiazoline and tail moieties of baringolin and antibacterial activity optimization. J. Med. Chem. 2014, 57, 4185-4195. [CrossRef] 
79. Just-Baringo, X.; Bruno, P.; Ottesen, L.K.; Cañedo, L.M.; Albericio, F.; Álvarez, M. Total synthesis and stereochemical assignment of baringolin. Angew. Chem. Int. Ed. 2013, 52, 7818-7821. [CrossRef]

80. Bagley, M.C.; Dale, J.W.; Merritt, E.A.; Xiong, X. Thiopeptide antibiotics. Chem. Rev. 2005, 105, 685-714. [CrossRef]

81. Yun, B.-S.; Hidaka, T.; Furihata, K.; Seto, H. Promothiocins A and B, novel thiopeptides with a tip A promoter inducing activity produced by Streptomyces sp. SF2741. J. Antibiot. 1994, 47, 510-514. [CrossRef]

82. Matsumoto, M.; Kawamura, Y.; Yasuda, Y.; Tanimoto, T.; Matsumoto, K.; Yoshida, T.; Shoji, J.I. Isolation and characterization of thioxamycin. J. Antibiot. 1989, 42, 1465-1469. [CrossRef]

83. Yun, B.-S.; Hidaka, T.; Furihata, K.; Seto, H. Microbial metabolites with tipA promoter inducing activity. III. Thioxamycin and its novel derivative, thioactin, two thiopeptides produced by Streptomyces sp. DP94. J. Antibiot. 1994, 47, 1541-1545. [CrossRef]

84. Murakami, T.; Holt, T.; Thompson, C. Thiostrepton-induced gene expression in Streptomyces lividans. J. Bacteriol. 1989, 171, 1459-1466. [CrossRef]

85. Anderson, B.; Hodgkin, D.C.; Viswamitra, M. The structure of thiostrepton. Nature 1970, 225, $233-235$. [CrossRef] [PubMed]

86. Holmes, D.; Caso, J.; Thompson, C. Autogenous transcriptional activation of a thiostrepton-induced gene in Streptomyces lividans. EMBO J. 1993, 12, 3183-3191. [CrossRef] [PubMed]

87. Yun, B.-S.; Fujita, K.-I.; Furihata, K.; Seto, H. Absolute stereochemistry and solution conformation of promothiocins. Tetrahedron 2001, 57, 9683-9687. [CrossRef]

88. Egawa, Y.; Umino, K.; Tamura, Y.; Shimizu, M.; Kaneko, K.; Sakurazawa, M.; Awataguchi, S.; Okuda, T. Sulfomycins, a series of new sulfur-containing antibiotics. I. J. Antibiot. 1969, 22, 12-17. [CrossRef] [PubMed]

89. Kohno, J.; Kameda, N.; Nishio, M.; Kinumaki, A.; Komaatsubara, S. The structures of sulfomycins II and III. J. Antibiot. 1996, 49, 1063-1065. [CrossRef] [PubMed]

90. Abe, H.; Kushida, K.; Shiobara, Y.; Kodama, M. The structures of sulfomycin I and berninamycin A. Tetrahedron Lett. 1988, 29, 1401-1404. [CrossRef]

91. Muir, L.A.; Rickes, E.L.; Duquette, P.F.; Smith, G.E. Prevention of induced lactic acidosis in cattle by thiopeptin. J. Anim. Sci. 1981, 52, 635-643. [CrossRef] [PubMed]

92. Debono, M.; Molloy, R.M.; Occolowitz, J.L.; Paschal, J.W.; Hunt, A.H.; Michel, K.H.; Martin, J.W. The structures of A10255 B,-G and-J: New thiopeptide antibiotics produced by Streptomyces gardneri. J. Org. Chem. 1992, 57, 5200-5208. [CrossRef]

93. Favret, M.E.; Boeck, L.V.D. Effect of cobalt and cyano-cobalamin on biosynthesis of A10255, a thiopeptide antibiotic complex. J. Antibiot. 1992, 45, 1809-1811. [CrossRef] [PubMed]

94. Vijaya Kumar, E.; Kenia, J.; Mukhopadhyay, T.; Nadkarni, S. Methylsulfomycin I, a new cyclic peptide antibiotic from a Streptomyces sp. HIL Y-9420704. J. Nat. Prod. 1999, 62, 1562-1564. [CrossRef] [PubMed] 